\title{
QUEEN'S
UNIVERSITY
BELFAST
}

\section{Assessment of the Vitreomacular Interface Using High-Resolution OCT in a Population-Based Cohort Study of Older Adults}

Quinn, N. B., Steel, D. H., Chakravarthy, U., Peto, T., Hamill, B., Muldrew, A., Graham, K., Elliott, D., Hennessy, R., Cruise, S., McGuinness, B., Young, I. S., Kee, F., \& Hogg, R. E. (2020). Assessment of the Vitreomacular Interface Using High-Resolution OCT in a Population-Based Cohort Study of Older Adults. Ophthalmology Retina, 4(8), 801-813. https://doi.org/10.1016/j.oret.2020.02.013

Published in:

Ophthalmology Retina

Document Version:

Peer reviewed version

Queen's University Belfast - Research Portal:

Link to publication record in Queen's University Belfast Research Portal

\section{Publisher rights}

Copyright 2020 Elsevier.

This manuscript is distributed under a Creative Commons Attribution-NonCommercial-NoDerivs License

(https://creativecommons.org/licenses/by-nc-nd/4.0/), which permits distribution and reproduction for non-commercial purposes, provided the author and source are cited.

\section{General rights}

Copyright for the publications made accessible via the Queen's University Belfast Research Portal is retained by the author(s) and / or other copyright owners and it is a condition of accessing these publications that users recognise and abide by the legal requirements associated with these rights.

Take down policy

The Research Portal is Queen's institutional repository that provides access to Queen's research output. Every effort has been made to ensure that content in the Research Portal does not infringe any person's rights, or applicable UK laws. If you discover content in the Research Portal that you believe breaches copyright or violates any law, please contact openaccess@qub.ac.uk. 


\section{Assessment of the Vitreomacular Interface Using High \\ 2 Resolution Optical Coherence Tomography in a \\ 3 \\ Population Based Cohort Study of Older Adults.}

Nicola B. Quinn*1, PhD, David H Steel ${ }^{\star 2}$ MD, Usha Chakravarthy ${ }^{1}$, MD PhD, Tunde Peto $^{1}$ MD PhD, Barbra Hamill ${ }^{1}$, BSc (Hons), Alyson Muldrew ${ }^{1}$ PhD, Katie Graham ${ }^{1}$ PhD, David Elliott ${ }^{1}$ BSc (Hons), Riona Hennessy ${ }^{1}$ BSc (Hons), Sharon Cruise ${ }^{1} \mathrm{PhD}$, Bernadette McGuinness ${ }^{1}$ MD, Ian S. Young ${ }^{1}$ MD, Frank Kee ${ }^{1}$ MD, Ruth E. Hogg ${ }^{1}$ PhD.

*Joint first authors

${ }^{1}$ Centre for Public Health, Queen's University Belfast, Belfast, UK

2 Sunderland Eye Infirmary Queen Alexandra Road, Sunderland, United Kingdom and Institute of Genetic Medicine, Newcastle University, Newcastle Upon Tyne, United Kingdom

Corresponding author: Ruth Hogg

Address:

Institute of Clinical Sciences, Block A,

Centre for Public Health,

Queen's University Belfast

Belfast, Northern Ireland BT12 6BA

Phone: $+44(0) 2890971654$

\section{Email: r.e.hogg@qub.ac.uk}

Financial support: Atlantic Philanthropies, ESRC, HSC Research and Development, OFMDFM, UKCRC and Queen's University Belfast provide core financial support for the Northern Ireland Cohort for the Longitudinal Study of Ageing (NICOLA). Macular Society, College of Optometrists and Diabetes UK funded individual researchers. The sponsors and funding organisations had no role in the design or conduct of this research.

No conflicting relationship exists for any author

Running head: Vitreomacular interface features in NICOLA

vitreomacular adhesion (VMA), vitreomacular interface (VMI), Vitreomacular traction (VMT), full thickness macular hole (FTMH), lamellar macular hole (LMH), age-related macular degeneration (AMD), epiretinal membrane (ERM), optical coherent tomography (OCT), the International Vitreomacular Traction Study (IVTS), spectral domain OCT (SD-OCT), Northern Ireland Cohort Study for the Longitudinal Study of Ageing (NICOLA), computer assisted home interview (CAPI), self-completion questionnaires (SCQ), Northern Ireland Clinical Research Facility (NICRF), Early Treatment Diabetic Retinopathy (ETDRS), Colour fundus photography (CFP), multicolour (MC), Network of Ophthalmic Reading Centres UK (NetWORC UK), psuedo macular hole $(\mathrm{PMH})$, macular hole $(\mathrm{MH})$, body mass index (BMI), 
37 systolic blood pressure (SBP), diastolic blood pressure (DBP), Choroidal neovascularisation 38 (CNV), geographic atrophy (GA), high-density lipoprotein cholesterol (HDL), confidence 39 intervals $(\mathrm{Cl})$, odds ratios (OR). 
Objective: To describe the prevalence of vitreomacular interface (VMI) features classified using spectral-domain optical coherence tomography (SD-OCT) and their associated risk factors in the Northern Ireland Cohort for the Longitudinal Study of Ageing (NICOLA Study).

Design: Cross-sectional population-based study

Participants: Non-institutionalised Northern Irish adults aged $\geq 40$ years.

Methods: Using geographic stratification, a representative sample of people in Northern Ireland was invited to participate in the NICOLA Study. SD-OCT images of participants were graded for vitreomacular traction (VMT), macular hole (MH) and epiretinal membrane (ERM) according to the International Vitreomacular Traction Study (IVTS) Group. A subsample was graded in more detail to estimate the prevalence of VMA and VMA area detailing size and location of VMA. Descriptive analysis and risk factors for each VMI feature was determined, using generalised estimating equations. Results were standardised to the Northern Ireland population census (2011).

Main outcome measures: Cohort profile, standardised prevalence and risk factor associations of each VMI feature.

Results: 3,358 NICOLA participants who attended the health assessment had gradable SD-OCT images available for at least one eye. The prevalence of VMT was 0.5\% (Cl 0.31\%-0.70\%), $\mathrm{MH} \mathrm{0.4 \%} \mathrm{(Cl} \mathrm{0.23 \% -0.52 \% )} \mathrm{and} \mathrm{ERM} \mathrm{7.6 \%} \mathrm{(Cl} \mathrm{7.0 \% -8.3 \% ).}$ The more detailed VMA analysis was done on a subsample consisting of the first 1,481 participants. The prevalence of VMA was 22.6\%, (Cl 21.1-24.2), VMA area ranged 
63 from $0.25 \mathrm{~mm}^{2}-42.7 \mathrm{~mm}^{2}($ mean=12.53, S.D = 6.90). In multivariate analysis increased age was associated with an increased odds ratio of VMT, MH and ERM. A lower visual acuity was associated with an increased odds ratio of VMT, MH and ERM. VMA area was positively associated with younger age and normal blood pressure. ERM and $\mathrm{MH}$

67 were more often present in more myopic eyes, an increase in levels of high-density 68 lipoprotein (HDL)-cholesterol and triglycerides.

69 Conclusion: The epidemiology of VMI features within a Northern Irish population was reported and indicate VMI interactions throughout life are age dependent. Vitreous separation reduced to a greater extent in the horizontal meridians compared to the vertical, differing to previous studies. Future longitudinal studies of the evolution of these VMI changes over time would be of great interest. 
83 As part of normal human ageing, vitreous liquefaction occurs with loss of the

homogenous gel structure present in early life. As a consequence of liquefaction and perhaps degradation of the normal mechanisms of vitreoretinal attachment, vitreous separation starts to occur first peripheral to the fovea, with later spontaneous vitreofoveal separation and finally vitreopapillary separation. A phase of vitreomacular adhesion (VMA) with gradually increasing perifoveal vitreous separation before complete posterior vitreous detachment, is thus a normal part of ageing. Due to the difficulty in detecting it clinically, age-related posterior vitreous detachment was initially thought to have quick onset and rapid progression however with the introduction of Bscan ultrasonography and optical coherence tomography (OCT) it is now known to progress slowly over a long period of time before complete separation of the vitreous occurs. ${ }^{1}$ Unfortunately, pathological alterations in this sequence of events can results in a variety of disorders, collectively known as vitreomacular interface (VMI) features. Vitreomacular traction (VMT) is the term given to the tractional changes observed when there is persistent and pathological attachment of the vitreous cortex to the fovea during the process of VMA resolution. This can lead full thickness macular hole (FTMH), but also in some cases lamellar macular hole (LMH), and has been implicated in the aetiology of other disease processes including diabetic maculopathy and wet age-related macular degeneration (AMD). Anomalous and incomplete vitreoretinal separation is also thought to be key to the process responsible for epiretinal membrane (ERM) formation. ${ }^{2-4}$

Recent advances in OCT has evoked considerable interest in the VMI as it now much better visualised and evaluated in a non-invasive manner. Evaluation of OCT images has revolutionised the understanding of VMI diseases and has increased in importance with the introduction of pharmacologic vitreolysis for the treatment of VMT 
or $\mathrm{FTMH}$ and focal VMA. ${ }^{5}$ A number of studies have described features of the $\mathrm{VMI}$ however there is heterogeneity in the definitions and classification of abnormalities making comparisons difficult. ${ }^{6-9}$ In 2013 , to address variations and inconsistencies in nomenclature, the International Vitreomacular Traction Study (IVTS) Group published a classification system for diseases of the VMI. ${ }^{10}$ It was designed with clinical applicability in mind as well as for use in research studies. Some studies have estimated VMI features using data obtained on attenders at hospital clinics ${ }^{11-15}$ which has the potential for introducing bias. The purpose of the present study is to report the prevalence of VMI features on spectral domain OCT (SD-OCT) images captured in a population setting using the definitions of the IVTS group. Furthermore, this is the first study to examine VMA area and dimensions in an aging population based study to better understand the natural progression of VMA as seen on SD-OCT.

\section{Methods}

\section{Participants}

122 In brief, the Northern Ireland Cohort Study for the Longitudinal Study of Ageing (NICOLA) is a multidisciplinary prospective population-based cohort study of the ageing population in Northern Ireland. The sampling strategy identified addresses within postcode-based geographic regions. A systematic sample was drawn from each postcode-based geographical stratum. ${ }^{16}$ Participation involved a computer assisted home interview (CAPI) conducted at the participant's home, a series of self-completion questionnaires (SCQ) and a health assessment conducted at the Northern Ireland Clinical Research Facility (NICRF) at Belfast City Hospital. Wave 1 of the study commenced in December 2013 and ended in April 2018. A total of 8452 persons completed the CAPI. Of these, 3420 (40.5\%) attended for the health assessment, 
consisting of anthropometric, cardiac, respiratory, cognitive and ophthalmic tests.

133 The ophthalmic tests included multi-modal retinal imaging using a standard retinal

134 fundus camera (Canon CX-1 Fundus Camera (Canon U.S.A., Inc.), wide-field retinal imaging (Optos plc, Dunfermline, UK) and SD-OCT imaging (Heidelberg Engineering, Heidelberg, Germany). The Early Treatment Diabetic Retinopathy (ETDRS) chart was used to test visual acuity. ${ }^{17}$ Visual acuity was recorded as the number of letters correctly identified from either the $4 \mathrm{~m}$ chart or the $1 \mathrm{~m}$ chart using a pinhole occluder. Autorefraction was measured using the auto-refractometer (Shin Nippon Accuref K900, Rexxam, Japan). Spherical equivalent was calculated using the standard formula (Spherical equivalent= sphere $+($ cylinder/2) $)$.

Ethical approval for the study was obtained from the School of Medicine, Dentistry and consent.

\section{Image acquisition}

Participants were given the option of having the pupils of neither (2592/6840, 37.9\%) one eye (right eye $=832 / 6840,12.2 \%$, left eye $=1424 / 6840,20.8 \%$ ) or both eyes dilated (1992/6840, 29.1\%). Colour fundus photography (CFP), and SD-OCT images were captured irrespective of pupillary dilation, whereas multicolour (MC) images were only captured in dilated eyes. CFP of the disc and macula with $50^{\circ}$ field of view was 
performed on the Canon CX-1 Digital Fundus Camera (Canon U.S.A., Inc, Tokyo, Japan). MC images had a $30^{\circ}$ field of view and a single macula centred image was obtained. Tomographic images (768 x768 pixels) were captured on the Spectralis SDOCT/CSLO (Heidelberg Engineering, Heidelberg, Germany). OCT was performed at a resolution of approximately $11 \mu \mathrm{m}$ per pixel. Each OCT volume scan was composed of 61 horizontal B-scan lines with a spacing of approximately $125 \mu \mathrm{m}$ on a $30^{\circ} \times 25^{\circ}$ (horizontal $x$ vertical) scan angle and was acquired using active eye tracking and automatic real-time mean image, an averaging of 8 scans per B-scan. The macula was well positioned at the centre of the image.

\section{VMI Grading}

\section{NICOLA Study VMI assessment}

Grading was conducted to a standardised protocol with screen settings at the highest available resolution (1920 x 1080). CFP were viewed on Oculab (V3.7.98.0). OCT and MC images were graded using the Heidelberg Eye Explorer Viewing Module 6.0.13.0 (Heidelberg Engineering, Heidelberg, Germany).

Trained graders within the Network of Ophthalmic Reading Centres UK (NetWORC UK) graded repository of images from the NICOLA study. All graders were certified for study specific grading achieving $70 \%$ concordance with the grading outcomes in the standard set and subsequently checked every 3 months for drift. The average certification score for graders was $87.9 \%$ concordance. The nomenclature and definitions of the IVTS Group classification, ${ }^{10}$ was used and graders recorded the features of VMT and macular hole (MH). MHs were subdivided into, 1) FTMH 2) LMH 
and 3) pseudomacular hole. VMT was further classified as, 1) inner retinal profile change only, 2) inner retinal changes with schitic spaces and 3) outer retinal change with sub retinal fluid. ERM were defined based on the Handan Eye Study, ${ }^{18}$ where an ERM was definitely present if detected on any part of the macula on either OCT or CFP (Supplementary material Table 1) (Figure 1).

\section{VMI assessment of sub sample}

In addition to the grading described above a more detailed evaluation of the VMI of the first 1500 consecutively enrolled NICOLA participants was undertaken by two independent masked trained graders:

Definition of VMA: Evidence of perifoveal vitreous cortex detachment from the retinal surface with no detectable change in foveal contour or underlying retinal tissues. ${ }^{10}$ within an area of diameter of $3000 \mu \mathrm{m}$ measured on the maximum foveal depression scan (Figure 1).

Determination of the area of VMA: All 61 B scans of the raster were scrutinized for evidence of vitreous detachment in either horizontal or vertical planes. The horizontal extent of VMA was measured on the B scan at the maximum foveal depression. To obtain this metric we determined the distance from the fovea to the nasal and temporal limits of the VMA (Figure 2A). The vertical extent of the VMA was obtained by identifying the most superior and inferior limits of the separation of the vitreous from the inner retina on the raster and recording the scan numbers (Figure $2 B \& 2 C$ ). The number of B scans enclosed within this set was multiplied by the distance between each B scan to obtain the vertical dimension of the VMA. Distance between each B scan was ascertained using the "image information" tab in the Heidelberg Eye Explorer Viewing Module 6.0.13.0 (Heidelberg Engineering, Heidelberg, Germany). The vertical 
and horizontal extents were multiplied to compute an approximate area of the VMA. If the VMA limits extended beyond the length of the foveal scan in any meridan or if the VMA did not involve the fovea the area of the VMA was not calculated.

\title{
Quality Control
}

\author{
NICOLA Study
}

All images exhibiting features of VMT and MH were reviewed by a retinal specialist. If ERM was recorded as present on both OCT and CFP no additional arbitration was performed. Arbitration was undertaken in eyes with ERM detected on a single imaging modality with no detection on any other modality.

\section{Subsample}

Inter-observer reliability was assessed in a subset of 100 images. There was near perfect inter-observer agreement for presence of VMA (Kappa statistic 0.92). Every 1 in 20 images were double regraded for presence of VMA. Using Bland-Altman plots inter-observer reliability for temporal measurements produced $95 \%$ limits of agreement of 13.92 to -114.6 , mean difference of 13.92 and no significant bias $(p=0.05)$. For nasal measurements the $95 \%$ limits of agreement were -96.08 to 131.44 , a mean difference of 17.68 and significant bias $(p<0.004)$.

\section{Statistical analysis}

\section{Covariate selection and categorisation}


224 Potential risk factors were selected based on a literature search or those related to putative mechanisms proposed by the study team, they included age, sex, ${ }^{7}$ body mass index $\left.\left(\mathrm{BMI} ; \mathrm{kg} / \mathrm{m}^{2}\right)\right)$, smoking, ${ }^{19}$ hypertension, spherical equivalent, ${ }^{20}$ visual acuity, ${ }^{21}$ plasma high-density lipoprotein (HDL)-cholesterol, triglycerides, $\mathrm{HbA} 1 \mathrm{c}^{22}$ and cataract. ${ }^{11} \mathrm{HbA} 1 \mathrm{c}$, triglycerides and $\mathrm{HDL}$ were measured on blood samples collected at the health assessment. Age was divided into three categories; 40-59 years, 60-69 years, and > 70 years. Hypertension was defined as normal (systolic blood pressure (SBP) $<120 \mathrm{~mm} \mathrm{Hg}$ and diastolic blood pressure (DBP) $<80 \mathrm{~mm} \mathrm{Hg}$ ); elevated (SBP 120-129 mm Hg and DBP <80 mm Hg); stage 1 hypertension (SBP 130-139 mm Hg or DBP $80-89 \mathrm{~mm} \mathrm{Hg}$ ); stage 2 hypertension (SBP $\geq 140 \mathrm{~mm} \mathrm{Hg}$ or DBP $\geq 90 \mathrm{~mm}$ Hg). ${ }^{23}$ Cataract status was categorised as pseudophakic, phakic cataract present and clear lens. Participants were categorised based on the HbA1c as no diabetes $<42 \mathrm{mmol} / \mathrm{mol}(<6 \%)$-, impaired glucose regulation 42 to $47 \mathrm{mmol} / \mathrm{mol}(6 \%-6.4 \%)-$ and diabetes $\geq 48 \mathrm{mmol} / \mathrm{mol}(\geq 6.5 \%) .{ }^{24}$ Smoking status was categorised as never, exsmokers and current. Choroidal neovascularisation (CNV), geographic atrophy (GA), retinal vein occlusions and diabetic retinopathy were considered as potentially confounding retinal diseases.

\section{Analysis}

Statistical analyses were performed using IBM SPSS Statistics (IBM Corp. Released 2011. IBM SPSS Statistics for Windows, Version 25. Armonk, NY: IBM Corp). Interobserver reliability was evaluated using kappa (K) statistics ${ }^{25}$ and Bland-Altman plot analyses. ${ }^{26}$ Data was weighted by age and gender using the 2011 Census for Northern Ireland. ${ }^{27}$ All statistics are given as a representative of the Northern Ireland population unless "unweighted" is stated. Frequency, prevalence and confidence intervals $(\mathrm{Cl})$ of 
each VMI feature was calculated. All variables were checked for normal distribution and collinearity. Chi-squared test or Fischer exact tests (parametric categorical variables), independent sample t-test (parametric continuous variables) or MannWhitney (non-parametric) were used to examine differences in characteristics according to gradable and ungradable OCT images, presence or absence of each VMI feature and VMA area. Adjusted odds ratios (OR) with 95\% Cls were then estimated for right and left eyes combined, using generalised estimating equations models to account for correlation between the 2 eyes. Interactions of each variable with age and sex was tested. Multivariate models included all variables that was significant in univariate analysis. Statistical significance was defined as $p<0.05$ (2-sided).

\section{Results}

260

In the current analysis the health assessment was undertaken by 3420 participants. Of these, $68(2 \%)$ participants refused imaging and in $1(0.03 \%)$ participant the images of both eyes were ungradable. Data from 3351(99.97\%) participants were available for analysis (Supplementary Figure 1); 3264(97.4\%) had images from both eyes and in $87(2.6 \%)$ images were available from one eye only $67(77 \%)$ had no left eye images captured and 15(17\%) no right eye images captured). A further 5(6\%) left eye images were deemed ungradable) resulting in 6615(96.7\%) images available for analysis (3336(50.4\%) right eye and 3279(49.6\%) left eye).

The weighted data characteristics of NICOLA participants with gradable images were compared with those without gradable images (Supplementary material Table 2). Participants with missing or ungradable images were significantly older and had poorer 271 visual acuity. Table 1 shows the overall characteristics of participants as well as those subdivided by the presence of VMT, MH and ERM in the NICOLA Study. In participants 
273 with gradable images the mean age was 62 (9.33), 57.3\% of participants were aged 40-59 years, of which $42.6 \%$ were aged 60 years and over. $53.1 \%$ of participants were female, there was a mean spherical equivalent of 0.60 (2.41) and $13.2 \%$ were psuedophakic. On univariate analysis participants with VMT, MH and ERM were older, had a lower visual acuity and had cataracts present compared with participants without these features. VMT were also more often present in participants that had cataract surgery, a higher spherical equivalent refraction whereas $\mathrm{MHs}$ and ERMs were more often present in participants with a lower spherical equivalent. ERMs were more often present in males, participants with lower levels of HDL and triglycerides, participants with stage 2 hypertension, pre diabetes and diabetes (Table 1).

\section{Prevalence of VMT, MH and ERM}

Table 2 shows the estimated age stratified prevalence of $\mathrm{VMT}, \mathrm{MH}$ and ERM in eyes of participants in the unweighted and weighted datasets. Unweighted represents the study sample prevalence whereas weighted represents the estimated prevalence for the Northern Ireland population.

\section{Vitreomacular Traction}

VMT was detected in 30 eyes $(0.5 \%, \mathrm{Cl} 0.31-0.70)$, and in 24 of these VMA was present in the fellow eye (80\%). The frequency of VMT in right eyes $(53 \%, 16 / 30)$ was similar to that in left eyes $(47 \%, 14 / 30, p=0.75)$. VMT was bilateral in 3 participants and unilateral in 24 participants. 26 VMT cases only had a change in the inner retinal profile present, whilst 4 also had inner retinal changes with schitic spaces present. 
297

298

299

300

301

302

303

304

305

306

307

308

309

310

311

312

313

314

315

316

317

VMT prevalence increased with age, from $0.1 \%$ in those aged $40-59$ years to $1.5 \%$ in those aged 70 or more years $(p<0.001)$. There was no difference in the prevalence of VMT between females $(14 / 27,51.9 \%)$ and males $(13 / 27,48.1 \%, p=0.89)$. In the multivariable model (Table 3), the odds of VMT increased with older age [60-69 $=\mathrm{OR}=7.07(95 \% \mathrm{Cl}$ 1.53-32.6, $\mathrm{p}=0.01), 70+=\mathrm{OR}=25.2(95 \% \mathrm{Cl}$ 5.92-107.7, $p<0.001)]$ and a lower visual acuity $\mathrm{OR}=0.97(95 \% \mathrm{Cl} 0.95-0.99, \mathrm{p}=0.001)$.

\section{Macular holes}

Macular holes were seen in a total of 23 eyes $(0.4 \%, \mathrm{Cl} 0.23-0.52)$. There was 7(30.4\%) pseudomacular holes, 14(60.9\%) LMHs and 2(8.7\%) FTMH present. The FTMHs detected were classified as large (range $529 \mu \mathrm{m}-665 \mu \mathrm{m}$ ), none had a VMT present in their fellow eye and all were present in participants aged 70 and over. The frequency of MHs in left eyes $(11 / 23,48 \%)$ was similar to that of right eyes $(12 / 23$, $52 \%, p=0.86)$. MHs were bilateral in one participant and unilateral in 21 participants. In the multivariate model (Table 3) the odds of MH increased with older age [60-69 $=\mathrm{OR}=4.62(95 \% \mathrm{Cl} 1.54-13.88, \mathrm{p}=0.01), 70+=\mathrm{OR}=4.65(95 \% \mathrm{Cl} 1.28-16.85$, $\mathrm{p}=0.02)], \mathrm{HDL}$ OR $=3.33(95 \% \mathrm{Cl} 1.64-6.53, \mathrm{p}<0.001)$, higher serum triglycerides $\mathrm{OR}=22.3(95 \% \mathrm{Cl} 2.90-171.2, \mathrm{p}=0.003)$, lower visual acuity $\mathrm{OR}=0.95(95 \% \mathrm{Cl} 0.94-$ 0.97, $\mathrm{p}<0.001)$ and a more myopic refractive error, $\mathrm{OR}=0.89(95 \% \mathrm{Cl} 0.85-0.95$, $p<0.001)$. 
319 ERMs were detected in a total of 503 eyes $(7.6 \%, \mathrm{Cl} 7.0-8.3)$. The frequency of ERMs

320 found in left eyes (61\% 308/503) was higher than that of right eyes $(196 / 503,39 \%$, $321 \mathrm{p}<0.001)$. ERMs were bilateral in 178 participants and unilateral in the rest. Prevalence 322 of ERMs increased with age, from $3.1 \%$ in those aged $40-59$ years to $18.9 \%$ in those 323 aged 70 years or more $(p<0.001)$. ERMs were found in $176(54.2 \%)$ males and 149 $324(45.8 \%)$ females $(p=0.01)$. In the multivariate model (Table 3 ) the odds of ERM 325 increased with older age $[60-69=\mathrm{OR}=1.97(95 \% \mathrm{Cl} 1.34-2.89, \mathrm{p}=0.001), 70+=$ $326 \mathrm{OR}=4.61(95 \% \mathrm{Cl} 3.08-6.90, \mathrm{p}<0.001)]$, higher serum triglycerides $\mathrm{OR}=2.11(95 \%$ $327 \mathrm{Cl} 1.06-4.21, \mathrm{p}=0.03)$, participants with cataracts $\mathrm{OR}=1.83(95 \% \mathrm{Cl} 1.26-2.64$, $328 \mathrm{p}=0.001)$, participants that have had cataract surgery OR $=3.55(95 \% \mathrm{Cl} 2.30-5.50$, $329 p<0.001)$, a lower visual acuity OR $=0.97(95 \% \mathrm{Cl} 0.97-0.98, p<0.001)$ and a more 330 myopic refractive error OR $=0.92(95 \% \mathrm{Cl} 0.88-0.96, p=0.001)$. The odds of ERM 331 decreased with female gender OR $=0.69(95 \% \mathrm{Cl} 0.52-0.91, p=0.01)$. 


\section{Relationships with other retinal conditions}

VMT and ERM were more likely present in eyes with other retinal diseases including those with CNV and retinal occlusions. MHs and ERM were more often present in eyes with GA present and VMT were more often present in eyes with diabetic retinopathy present (Supplementary table 3).

\section{Subsample}

In the unweighted subsample of the first 1500 consecutive participants whose images were subjected to a more detailed grading, 2933(97.8\%) images were available for analysis (53(1.7\%) not captured and 14(0.5\%) ungradable). The weighted prevalence of VMA was 22.6\%, (Cl 21.1-24.2), VMT, 0.3\% (Cl 0.14-0.54), $\mathrm{MH}, 0.1 \%(\mathrm{Cl} 0.00-$ 0.20) and ERM, 9.7\% (Cl 8.66-10.80). For VMT, MH and ERMs similar prevalence was found to that observed in the overall NICOLA sample.

\section{Vitreomacular Adhesions and Area}

Table 4 shows the characteristics of participants with and without VMA in at least one eye on univariate analysis. Participants with a VMA were older than those without in the $60-69$ age group (26.5\% vs $19.2 \%)$ however in the $70+$ age group participants without a VMA were older than participants with a VMA (26.5\% vs $14.6 \%)$. VMA was more likely to be undetected in eyes with a past history of cataract surgery. On univariate analysis participants with and without VMA did not differ for other characteristics (gender, BMI, HDL, triglycerides, visual acuity, spherical equivalent, HbA1c, hypertension status and smoking) (Table 4). 
The frequency of VMA in right eyes $(51.0 \%, 342 / 670)$ was similar to that in left eyes (49.0\%, 328/670, $\mathrm{p}=0.54)$. VMA was bilateral in 269 participants and unilateral in the rest. In the multivariate model (Table 4) the odds of VMA increased in participants age 60-69 $[60-69=\mathrm{OR}=1.27(95 \% \mathrm{Cl} 1.05-1.55, \mathrm{p}=0.02)$ and becomes less common in the $70+$ age group $[70+=\mathrm{OR}=0.57(95 \% \mathrm{Cl} 0.42-0.76, \mathrm{p}<0.0001)]$, and participants with impaired glucose regulation OR $=1.32(95 \% \mathrm{Cl} 1.04-1.67, \mathrm{p}=0.02)$. The odds of VMA decreased with female gender $\mathrm{OR}=0.79(95 \% \mathrm{Cl} 0.66-0.94, \mathrm{p}=0.01)$ and psuedophakic eyes OR $=0.50(95 \% \mathrm{Cl} 0.30-0.83, \mathrm{p}=0.01)$.

On examining the area of VMA in the 1040 participants with evidence of vitreous separation on both horizontal and vertical meridians. The minimum area was $0.25 \mathrm{~mm}^{2}$ and the maximum was $42.7 \mathrm{~mm}^{2}(\operatorname{mean}=12.53, \mathrm{~S} . \mathrm{D}=6.90)$. The presence of VMA was the highest in the superior region (96.3\%) followed by the nasal region $(94.4 \%)$, temporal region (90.9\%) and finally the inferior region (58.6\%). The mean measurements for superior, nasal, temporal, and inferior sectors was $2.27 \mathrm{~mm}$ (S.D = $0.56), 1.92 \mathrm{~mm}(S . D=0.73), 1.89 \mathrm{~mm}(S . D=0.68)$ and $2.22 \mathrm{~mm}(S . D=0.58)$ respectively. Extent of vitreous separation with age groups shows a consistent effect of nasal and temporal adhesions reducing throughout age groups whilst superior and inferior adhesions remained constant (Figure 3A). Figure 3B shows the extent of VMA area by age and gender. VMA area decreased and was the similar between male and females in each age group. In the $80+$ age group female participants had a smaller VMA area when compared to participants in the 40-49 and 50-59 age groups.

An increase in VMA area was associated with younger age [60-69 $=\mathrm{OR}=0.03(95 \%$ $\mathrm{Cl} 0.01-0.09, \mathrm{p}<0.001), 70+=\mathrm{OR}=0.001(95 \% \mathrm{Cl} 0.00-0.01, \mathrm{p}<0.001)]$. VMA area increased in participants with a higher spherical acuity OR = $1.23(95 \% \mathrm{Cl}$ 1.02-1.48, 
$\mathrm{p}=0.03$ ) and normal blood pressure compared to participants with stage 2 hypertension OR $=0.21(95 \% \mathrm{Cl} 0.06-0.67, \mathrm{p}=0.01)($ Table 4$)$.

\section{Discussion}

The purpose of this study was to report on the epidemiology of VMI features in a population based study. Most population based study prevalence estimates of VMI abnormalities are based on detection using fundus images. ${ }^{28,29}$ In this study we used multimodal imaging and particularly relied on the SD-OCT to report on the status of the VMI. To the best of our knowledge this is the first population study that provides estimates of the dimensions of VMA in an older population, and the first study that examines its dimensions in a Caucasian population.

VMA was defined as evidence of perifoveal vitreous cortex detachment from the retinal surface with no detectable change in foveal contour or underlying retinal tissues. VMA was measured on the maximum foveal depression scan and recorded as present if the sum of the nasal and/or temporal limits did not exceed $3000 \mu \mathrm{m}$. The overall prevalence of VMA within the present study was $22.6 \%$, a similar prevalence of VMA was found in the Beaver Dam Eye Study (26\%) where SDOCT was also used. ${ }^{30}$ The information on prevalence of VMI features on SD-OCT within a population based study is largely lacking with most data coming from hospital based studies or disease specific studies. ${ }^{11-15,31-33}$ Previous prevalence data on VMA varies greatly (14.74\%40.6\%); ${ }^{31,34,35}$ with differences between VMA prevalence reported in the current study and other published literature likely due to the significant heterogeneity in the definitions, classification of conditions used, methods of detection and/or the study sample analysed. ${ }^{9}$ In keeping with other studies, we found participants with impaired 
glucose regulation more often had a VMA present, ${ }^{36-38}$ VMA has been shown to be a

404

405

406

407

408

409

410

411

412

413

414

415

416

417

418

419

420

421

422

423

424

425

426

characteristic change in proliferative diabetic retinopathy causing worsening of the proliferative process compared to eyes with no detachment or complete detachment. ${ }^{38,39}$ Although participants classified as having diabetes in this study showed no association with VMA, participants with impaired glucose regulation did, few studies have examined the pre diabetes stage and its association with VMA using HbA1c therefore perhaps VMA manifests earlier in the disease process than initially thought. In this study VMA increased with age in the 60-69 age group and decreased in the $70+$ age group compared to the $40-59$ age group. The decrease in odds of VMA found in the 70+ age group supports the view that the VMA in these participants progress to complete posterior vitreous detachment. The lower prevalence in the $70+$ age group may be related to the timing of vitreous detachment. The process of detachment begins around the macula, then the centre of the macula, followed by the disc, and finally there is a complete posterior vitreous detachment in older subjects. ${ }^{9}$ The lack of gender difference for VMA is interesting and agrees with the lack of gender difference with VMT, however different to that of FTMH which has a higher incidence in females. ${ }^{40}$ VMA was less likely found in phakic eyes and pseudophakic eyes in the NICOLA Study, supporting the findings in the Alienor Study. ${ }^{11}$ This supports the view that movement and biochemical changes in the vitreous during and after cataract surgery can result in the vitreous becoming fully detached. ${ }^{41}$ In this study VMA was more likely present in males than females. If we believe a VMA is considered as a precursor of complete posterior vitreous detachment of the vitreous the results in this study are concordant with previous studies ${ }^{6,42}$ where complete detachment of the vitreous was associated with female gender. 
427 In addition we have provided metrics on the limits of attachment and the patterns of separation. We showed that the area of VMA was larger in younger participants which is consistent with findings by Palacio et al where they looked at healthy subjects without clinical pathology over nine decades of life. ${ }^{43} \mathrm{VMA}$ area was also found to be larger in participants with a higher spherical equivalent and normal blood pressure. It is uncertain if the association between larger VMA area and normal blood pressure is a real or coincidental as it hasn't been found before and we do not have a hypothesis for the mechanism underlying this finding. This is the first study to look at multiple associations with VMA area and while some are easily explained mechanistically, others are not and will require replication and further investigation in other cohorts. Few studies have charted the sequence of vitreous separation in normal eyes. We found that evidence of vitreous separation was greatest superiorly followed by nasally, temporally and inferiorly. Superior vitreous separation has been consistently recorded at higher levels than inferiorly in other studies, presumably secondary to gravity.9,44 We found however that the length of persistent VMA was lowest horizontally, the opposite of previous studies ${ }^{6,45}$ from east Asian countries suggesting ethnic differences may affect the pattern of vitreous separation.

The prevalence of VMT using the definition provided in the IVTS Group ${ }^{10}$ was similar in the NICOLA Study (0.5\%) compared to that seen by a hospital based study carried out in Spain (0.6\%). ${ }^{46}$ When compared to other population based studies the prevalence of VMT in the NICOLA Study was noticeably lower to that reported by the Beaver Dam Eye Study (1.6\%) which in turn was different from that of the Beijing Eye Study (2.4\%). The higher prevalence in the Beijing Eye Study may be related to the fact that myopia which is highly prevalent in China is associated with VMT. We also observed an association between older age and lower visual acuity with the presence 
452 of VMT consistent with the Beaver Dam Eye Study and other studies. ${ }^{6,7}$ The higher prevalence of VMT found in the Beaver Dam Eye Study compared to the NICOLA Study may be due to the age profile used in each study. In the Beaver Dam Eye Study the mean age was 74.1 years (range $43-84$ years) compared to a mean age of 62 years (range 40-96 years) in the NICOLA Study.

The overall prevalence of MHs, which included FTMH, LMH and pseudomacular holes within the NICOLA Study was $0.4 \%$. Currently available prevalence data on $\mathrm{MHs}$ varies. ${ }^{28,29,47}$ In the NICOLA Study all cases of full thickness $\mathrm{MH}(\mathrm{n}=3)$ occurred in the older participants (>70+ years) ${ }^{48}$ and had reduced visual acuity. ${ }^{49}$ Although the numbers were few we found a weak association with high HDL, triglycerides and highly myopic eyes. Vitreous liquefaction and degeneration with development of traction, lower concentrations of collagen, proteins and hyaluronic acid in myopic eyes are likely factors in the developments of macular holes of all three subtypes. ${ }^{50}$

ERMs were observed at a prevalence of $7.6 \%$ and similar to that seen in the Blue Mountains Study $(7 \%)^{28}$, the Melbourne Visual Impairment Project $(6 \%)^{51}$ and the Maastricht Study. ${ }^{52}$ When compared to some of the other population based studies the rate observed in the NICOLA Study is considerably higher ${ }^{53,18}$ but lower than of the Beaver Dam Eye Study $(34.1 \%)^{7}$ and Los Angeles Latino Eye Study (19.9\%). ${ }^{54}$ These differences likely attributable to the imaging methods and the definitions used to grade ERMs. Nonetheless we observed similarities in that the prevalence of ERMs increased strongly with age from $23 \%$ in those aged $40-59$ years to $54 \%$ in those aged 70 years or more $(p<0.001) .{ }^{46,52,55}$ Not surprisingly, we found that presenting visual acuity was significantly worse in participants with an ERM than those without, ${ }^{28,29}$ and the prevalence of ERM was higher in pseudophakes when compared to participants with a clear lens and those with retinal vascular occlusions and CNV. ${ }^{18,29}$ Interestingly 
477 the prevalence of ERM was also higher in phakic eyes with cataract when compared 478 to clear lens perhaps suggesting a genetic association. Our study also showed that more myopic eyes were at risk of ERM, similar to that reported in the Singapore Indian 480 Eye Study and The Handan Eye Study and Melbourne Visual Impairment 481 Project. ${ }^{18,20,51}$

Our study has several strengths. It is the first population based study to report on the health of the VMI and associations with risk factors. We used standardised protocols to acquire and grade SD-OCT images. A limitation of our study in common with other studies previously undertaken was our inability to identify a complete vitreous detachment from a complete attachment of the vitreous as only a small area of the retina is included in the scan area and ultrasound was not performed. Another limitation was the low response rate with only some $40.5 \%$ of the participants who completed the CAPI willing to attend the clinical assessment. When comparing the attending group (40.5\%) to the non-attending group there was a higher percentage of females in the non-attending group (57.5\%) compared to the attending group $(52.1 \%)$ $(p<0.001)$ with non-attending participants being older $(70+$ age group $=37.8 \%$ vs $25 \%$, $\mathrm{p}<0.001)$. There was also a higher percentage of current smokers in the non-attending group $(21.1 \%)$ when compared to the attending group $(10.1 \%)(p<0.001)$. However, we attempted to minimise the potential impact through the use of population based weightings of age and gender.

In conclusion, we have described normal and pathological changes in the VMI in an ageing Caucasian population. Vitreomacular adhesion is shown to reduce gradually with age after onset, and reduced in prevalence with vitreous separation in pseudophakic eyes and females. In this population it reduced to a greater extent in the 
501 horizontal meridians compared to the vertical, in contradistinction to previous studies 502 in other ethnic groups. ERMs increased in prevalence with age reaching a prevalence

503 of $19 \%$ in those over 70 years old, and were commoner in men and pseudophakic 504 eyes. VMT and macular holes were much rarer at $0.5 \%$ overall, but again increasing 505 in prevalence with age. The study was a cross sectional population based study and 506 longitudinal studies of the evolution of these VMI changes over time would be of great 507 interest.

Acknowledgements: We are grateful to all the participants of the NICOLA Study, and the whole NICOLA team, which includes nursing staff, research scientists, clerical staff, computer and laboratory technicians, managers and receptionists. The Atlantic Philanthropies, the Economic and Social Research Council, the UKCRC Centre of

513 Excellence for Public Health Northern Ireland, the Centre for Ageing Research and Development in Ireland, the Office of the First Minister and Deputy First Minister, the Health and Social Care Research and Development Division of the Public Health Agency, the Wellcome Trust/Wolfson Foundation and Queen's University Belfast provide core financial support for NICOLA. The authors alone are responsible for the interpretation of the data and any views or opinions presented are solely those of the authors and do not necessarily represent those of the NICOLA Study team. 
References

534 1. Johnson MW. How should we release vitreomacular traction: Surgically, 535 pharmacologically, or pneumatically? Am J Ophthalmol. 2013;155(2):203-205. e1.

536 2. Kampik A. Pathology of epiretinal membrane, idiopathic macular hole, and vitreomacular 537 traction syndrome. Retina. 2012;32 Suppl 2:S194-8; discussion S198-9. doi: 538 10.1097/IAE.0b013e31825bc20a [doi].

539 3. Sebag J. Anomalous posterior vitreous detachment: A unifying concept in vitreo-retinal 540 disease. Graefe's archive for clinical and experimental ophthalmology. 2004;242(8):690-698.

541 4. Hikichi T, Takahashi M, Trempe CL, Schepens CL. Relationship between premacular 542 cortical vitreous defects and idiopathic premacular fibrosis. Retina. 1995;15(5):413-416.

543 5. Stalmans P, Duker JS, Kaiser PK, et al. Oct-based interpretation of the vitreomacular 544 interface and indications for pharmacologic vitreolysis. Retina. 2013;33(10):2003-2011.

545 6. Shao L, Xu L, You QS, et al. Prevalence and associations of incomplete posterior vitreous 546 detachment in adult chinese: The beijing eye study. PLoS One. 2013;8(3):e58498. 
547 7. Meuer SM, Myers CE, Klein BE, et al. The epidemiology of vitreoretinal interface

548 abnormalities as detected by spectral-domain optical coherence tomography: The beaver 549 dam eye study. Ophthalmology. 2015;122(4):787-795. doi: 10.1016/j.ophtha.2014.10.014 550 [doi].

551 8. Levison AL, Kaiser PK. Vitreomacular interface diseases: Diagnosis and management. 552 Taiwan Journal of Ophthalmology. 2014;4(2):63-68.

553 9. Uchino E, Uemura A, Ohba N. Initial stages of posterior vitreous detachment in healthy 554 eyes of older persons evaluated by optical coherence tomography. Arch Ophthalmol. $555 \quad 2001 ; 119(10): 1475-1479$.

556 10. Duker JS, Kaiser PK, Binder S, et al. The international vitreomacular traction study group 557 classification of vitreomacular adhesion, traction, and macular hole. Ophthalmology. $558 \quad 2013 ; 120(12): 2611-2619$.

559 11. Gattoussi S, Cougnard-Grégoire A, Delyfer M, et al. Vitreomacular adhesion and its 560 association with age-related macular degeneration in a population-based setting: The alienor 561 study. Invest Ophthalmol Vis Sci. 2017;58(4):2180-2186. 12. Yang $Y$, Yan $Y N$, Wang $Y X$, et al. Ten-year cumulative incidence of epiretinal membranes assessed on fundus photographs. the beijing eye study 2001/2011. PloS one. 564 2018;13(4):e0195768.

565 13. Shen Z, Duan X, Wang F, et al. Prevalence and risk factors of posterior vitreous 566 detachment in a chinese adult population: The handan eye study. BMC ophthalmology. $567 \quad 2013 ; 13(1): 33$. 14. Carrero JL. Incomplete posterior vitreous detachment: Prevalence and clinical relevance. Am J Ophthalmol. 2012;153(3):497-503. 
570 15. Miyoshi Y, Tsujikawa A, Manabe S, et al. Prevalence, characteristics, and pathogenesis

571 of paravascular inner retinal defects associated with epiretinal membranes. Graefe's Archive

572 for Clinical and Experimental Ophthalmology. 2016;254(10):1941-1949.

573 16. Cruise S, Kee F. Early key findings from a study of older people in northern ireland: The 574 NICOLA study. Northern Ireland Cohort for the Longitudinal Study of Ageing, Centre for ...; 5752017.

576 17. Ferris III FL, Kassoff A, Bresnick GH, Bailey I. New visual acuity charts for clinical 577 research. Am J Ophthalmol. 1982;94(1):91-96. 18. Duan XR, Liang YB, Friedman DS, et al. Prevalence and associations of epiretinal membranes in a rural chinese adult population: The handan eye study. Invest Ophthalmol Vis Sci. 2009;50(5):2018-2023.

19. Wang S, Tong Q, Wang H, Lu Q, Xu Y. The association between smoking and epiretinal membrane. Scientific reports. 2016;6:38038.

20. Koh V, Cheung CY, Wong W, et al. Prevalence and risk factors of epiretinal membrane in asian indians. Invest Ophthalmol Vis Sci. 2012;53(2):1018-1022. adults with visual impairment in the UK biobank study: Prevalence, impact on visual acuity and associations. BMJ open ophthalmology. 2017;1(1):e000057. patients with diabetic macular oedema and their implications on the response to anti-VEGF therapy. Graefe's Archive for Clinical and Experimental Ophthalmology. 2018;256(8):14111418. 
592 23. Whelton PK, Carey RM. The 2017 clinical practice guideline for high blood pressure.

593 JAMA. 2017;318(21):2073-2074.

594 24. Diabetes UK. HbA1c test for diabetes. https://www.diabetes.co.uk/hba1c-test.html.

$595 \quad$ Updated 2019. Accessed 03/29, 2019.

596 25. McHugh ML. Interrater reliability: The kappa statistic. Biochemia medica: Biochemia 597 medica. 2012;22(3):276-282.

598 26. Giavarina D. Understanding bland altman analysis. Biochem Med (Zagreb).

599 2015;25(2):141-151. doi: 10.11613/BM.2015.015 [doi].

600 27. Northern Ireland Statistics \& Research Agency. Census 2011 population tables.

601 https://www.nisra.gov.uk/sites/nisra.gov.uk/files/publications/2011-census-results-population-

602 estimates-summary-tables-25-september-2014.pdf. Updated 2014. Accessed 06/18, 2019.

28. Mitchell P, Smith W, Chey T, Wang JJ, Chang A. Prevalence and associations of

604 epiretinal membranes: The blue mountains eye study, australia. Ophthalmology.

605 1997;104(6):1033-1040.

29. Klein R, Klein BE, Wang Q, Moss SE. The epidemiology of epiretinal membranes. Trans Am Ophthalmol Soc. 1994;92:403-25; discussion 425-30.

30. Meuer SM, Myers CE, Klein BE, et al. The epidemiology of vitreoretinal interface abnormalities as detected by spectral-domain optical coherence tomography: The beaver dam eye study. Ophthalmology. 2015;122(4):787-795.

612 coherence tomography analysis in the retina clinic setting. Clinical ophthalmology (Auckland, NZ). 2016;10:627. 
32. Yang $Y$, Yan YN, Wang YX, et al. Ten-year cumulative incidence of epiretinal membranes assessed on fundus photographs. the beijing eye study 2001/2011. PloS one. 2018;13(4):e0195768.

33. Wong Y, Steel DH, Habib MS, et al. Vitreoretinal interface abnormalities in patients treatedwith ranibizumab for diabetic macular oedema. Graefe's Archive for Clinical and Experimental Ophthalmology. 2017;255(4):733-742.

34. Rodman JA, Shechtman D, Sutton BM, Pizzimenti JJ, Bittner AK, VAST Study Group. Prevalence of vitreomacular adhesion in patients without maculopathy older than 40 years. Retina. 2018;38(10):2056-2063. doi: 10.1097/IAE.0000000000001792 [doi].

35. Jacob J, Stalmans P. Prevalence of vitreoretinal interface abnormalities as detected by spectral-domain optical coherence tomography. Ophthalmologica. 2016;236(2):81-87.

36. Kakehashi A, Kado M, Akiba J, Hirokawa H. Variations of posterior vitreous detachment. Br J Ophthalmol. 1997;81(7):527-532.

37. Ophir A, Martinez MR. Epiretinal membranes and incomplete posterior vitreous detachment in diabetic macular edema, detected by spectral-domain optical coherence tomography. Invest Ophthalmol Vis Sci. 2011;52(9):6414-6420.

38. Takahashi M, Trempe CL, Maguire K, McMeel JW. Vitreoretinal relationship in diabetic retinopathy: A biomicroscopic evaluation. Arch Ophthalmol. 1981;99(2):241-245.

39. Gaucher D, Tadayoni R, Erginay A, Haouchine B, Gaudric A, Massin P. Optical coherence tomography assessment of the vitreoretinal relationship in diabetic macular edema. Am J Ophthalmol. 2005;139(5):807-813.

40. Syed Z, Stewart MW. Age-dependent vitreous separation from the macula in a clinic population. Clinical ophthalmology (Auckland, NZ). 2016;10:1237. 
41. Stalmans P, Benz MS, Gandorfer A, et al. Enzymatic vitreolysis with ocriplasmin for vitreomacular traction and macular holes. N Engl J Med. 2012;367(7):606-615.

42. Hayreh SS, Jonas JB. Posterior vitreous detachment: Clinical correlations. Ophthalmologica. 2004;218(5):333-343. doi: 10.1159/000079476 [doi].

43. Palacio AC, Gupta A, Nesmith BL, Jadav PR, Schaal Y, Schaal S. Vitreomacular adhesion evolution with age in healthy human eyes. Retina. 2017;37(1):118-123.

44. de Smet MD, Gad Elkareem AM, Zwinderman AH. The vitreous, the retinal interface in ocular health and disease. Ophthalmologica. 2013;230(4):165-178. doi: 10.1159/000353447 [doi].

45. Tsukahara M, Mori K, Gehlbach PL, Mori K. Posterior vitreous detachment as observed by wide-angle OCT imaging. Ophthalmology. 2018;125(9):1372-1383.

46. Zapata MA, Figueroa MS, González EE, et al. Prevalence of vitreoretinal interface abnormalities on spectral-domain OCT in healthy participants over 45 years of age. Ophthalmology Retina. 2017;1(3):249-254.

47. Rahmani B, Tielsch JM, Katz J, et al. The cause-specific prevalence of visual impairment in an urban population: The baltimore eye survey. Ophthalmology. 1996;103(11):1721-1726.

48. Ali FS, Stein JD, Blachley TS, Ackley S, Stewart JM. Incidence of and risk factors for developing idiopathic macular hole among a diverse group of patients throughout the united states. JAMA ophthalmology. 2017;135(4):299-305.

49. Steel DH, Lotery AJ. Idiopathic vitreomacular traction and macular hole: A comprehensive review of pathophysiology, diagnosis, and treatment. Eye. 2013;27(S1):S1.

50. Kobayashi H, Kobayashi K, Okinami S. Macular hole and myopic refraction. $\mathrm{Br} \mathrm{J}$ Ophthalmol. 2002;86(11):1269-1273. doi: 10.1136/bjo.86.11.1269 [doi]. 

membranes in the visual impairment project. Am J Ophthalmol. 2005;140(2):288. e1-288. e8.

52. Liesenborghs I, De Clerck EE, Berendschot TT, et al. Prevalence of optical coherence tomography detected vitreomacular interface disorders: The maastricht study. Acta Ophthalmol. 2018;96(7):729-736.

53. You Q, Xu L, Jonas J. Prevalence and associations of epiretinal membranes in adult chinese: The beijing eye study. Eye. 2008;22(7):874.

54. Fraser-Bell S, Ying-Lai M, Klein R, Varma R. Prevalence and associations of epiretinal membranes in latinos: The los angeles latino eye study. Invest Ophthalmol Vis Sci. 2004;45(6):1732-1736.

55. Xiao W, Chen X, Yan W, Zhu Z, He M. Prevalence and risk factors of epiretinal membranes: A systematic review and meta-analysis of population-based studies. BMJ Open. 2017;7(9):e014644-2016-014644. doi: 10.1136/bmjopen-2016-014644 [doi].

\section{Figures}

680 Figure 1 An example of a vitreomacular adhesion from the NICOLA study. A: White 681 arrows shows the first point of vitreous separation from the surface of the retina at 682 the nasal and temporal limits, B: White arrow shows attachment of the vitreous with 683 distortion of the foveal surface. C: Lamellar macular hole with irregular foveal contour 684 (white arrow), photoreceptor layer remains intact. D: Epiretinal membrane, white 685 arrows point to the thin hyper reflective band on the neurosensory retina. In regions 
686

where there is separation of the hyper reflective band from the retina puckering is seen.

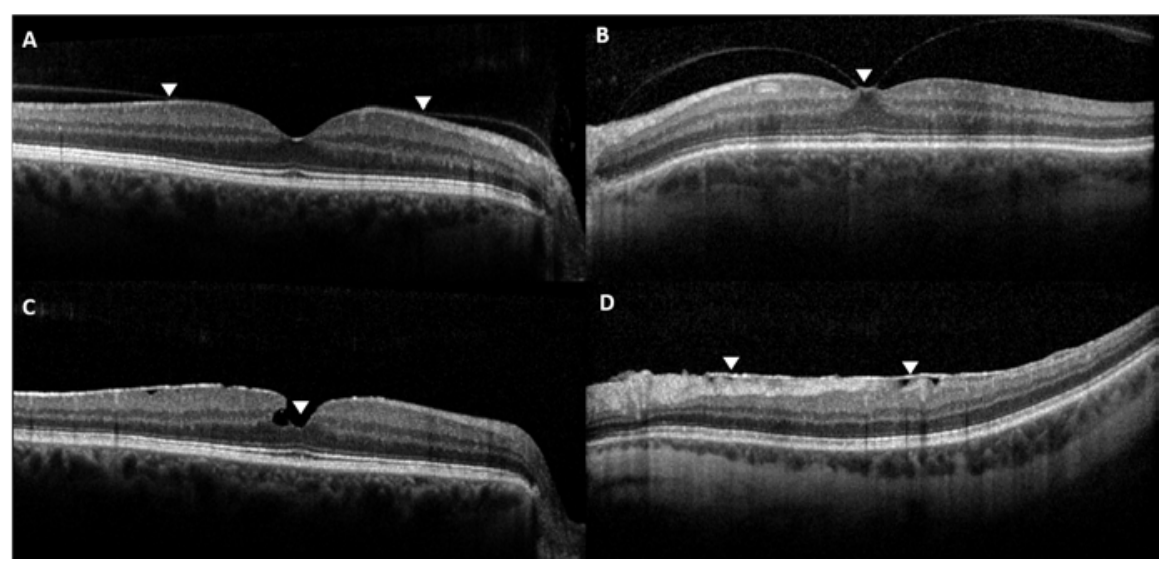

Figure 2 A: Nasal $(1903 \mu \mathrm{m})$ and temporal $(1918 \mu \mathrm{m})$ limits of detachment (white arrows) measured on the B scan transecting the maximum foveal depression site. $B$ : The superior most B scan (48/61) showing complete separation between the vitreous and the internal limiting membrane across the entire length of the scan. $\mathrm{C}$ : The inferior most B scan (8/61) showing complete separation between the vitreous and internal limiting membrane along the entire length of the scan.

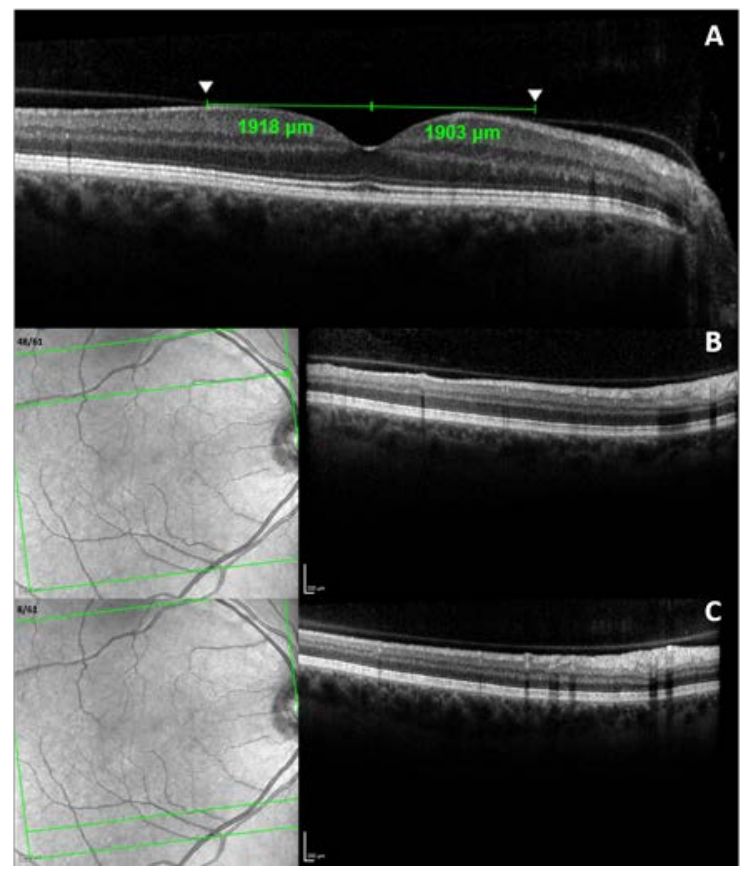

Figure 3 A: Bar graph showing the extent of vitreomacular adhesion measured from the maximum foveal depression site for each sector on the retina (superior, inferior, nasal and temporal) with age. Superior and inferior measurements remained constant with age whereas the nasal and temporal measurements consistently decreased with increasing age. B: Graph showing the extent of vitreomacular adhesion area by age and gender. Area of vitreomacular adhesion decreased with age and was similar between male and females with the exception of females in the 
$80+$ group where vitreomacular adhesion area was smaller than that of females aged 40-59 years.

A

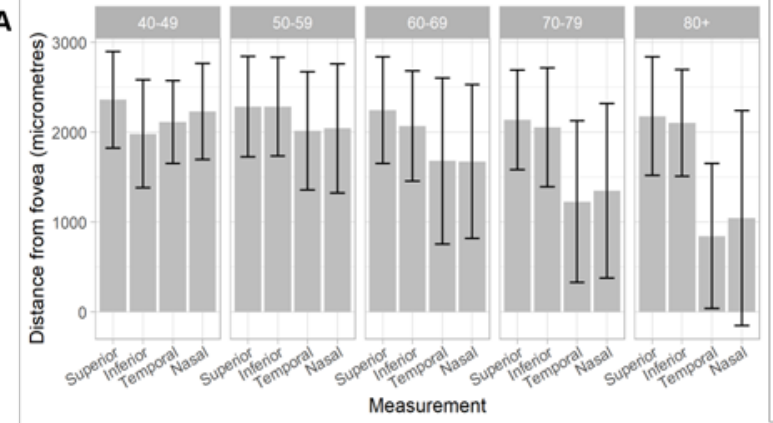

705

B

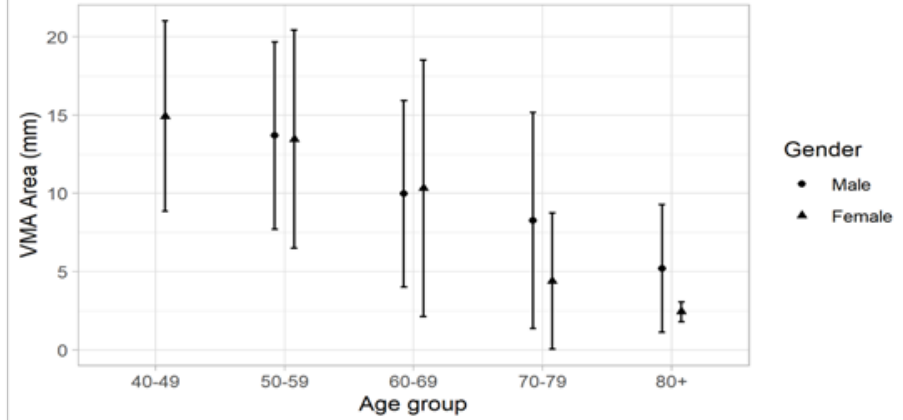

706

707 
Table 1. Characteristics of participants with gradable images and according to vitreomacular interface status. Weights were applied

\begin{tabular}{|c|c|c|c|c|c|c|c|c|c|c|c|}
\hline Characteristic & & $\begin{array}{l}\text { Participants } \\
\text { with gradable } \\
\text { images }\end{array}$ & $\begin{array}{l}\text { Vitreomacular } \\
\text { Traction } \\
\text { Present }\end{array}$ & $\begin{array}{l}\text { Vitreomacular } \\
\text { Traction } \\
\text { Absent }\end{array}$ & \begin{tabular}{|l|}
$p$ \\
value
\end{tabular} & $\begin{array}{l}\text { Macular } \\
\text { Hole } \\
\text { Present }\end{array}$ & $\begin{array}{l}\text { Macular } \\
\text { Hole } \\
\text { Absent }\end{array}$ & $p$ value & $\begin{array}{l}\text { Epiretinal } \\
\text { Membrane } \\
\text { Present }\end{array}$ & $\begin{array}{l}\text { Epiretinal } \\
\text { Membrane } \\
\text { Absent }\end{array}$ & $p$ value \\
\hline Number & & $\mathrm{N}=3358$ & $\mathrm{~N}=\mathbf{2 7}$ & $\mathrm{N}=\mathbf{3 3 3 1}$ & & $\mathrm{N}=22$ & $\mathrm{~N}=\mathbf{3 3 3 6}$ & & $N=325$ & $\mathrm{~N}=\mathbf{3 0 3 3}$ & \\
\hline \multirow{3}{*}{$\begin{array}{ll}\text { Age } & \text { group } \\
\mathrm{n}(\%) & \end{array}$} & $40-59$ & 1926 (57.3) & $2(7.4)$ & $1924(57.8)$ & \multirow[t]{3}{*}{$<0.001$} & $3(14.6)$ & $\begin{array}{l}1922 \\
(57.6)\end{array}$ & \multirow[t]{3}{*}{$<0.001$} & $79(24.3)$ & $1847(60.9)$ & \multirow[t]{3}{*}{$<0.001$} \\
\hline & $60-69$ & $703(20.9)$ & $6(22.2)$ & $697(20.9)$ & & $8(38.1)$ & $695(20.8)$ & & $75(23.1)$ & $628(20.7)$ & \\
\hline & $70+$ & 729 (21.7) & $19(70.4)$ & $710(21.3)$ & & $11(47.3)$ & 719 (21.6) & & $171(52.6)$ & $558(18.4)$ & \\
\hline \multirow[t]{2}{*}{ Gender $n(\%)$} & Female & $1784(53.1)$ & $14(52)$ & 1770 (53.1) & \multirow[t]{2}{*}{0.89} & $13(59.1)$ & $\begin{array}{l}1771 \\
(53.1)\end{array}$ & \multirow[t]{2}{*}{0.57} & $149(45.8)$ & 1635(53.9) & \multirow[t]{2}{*}{0.01} \\
\hline & Male & 1574 (46.9) & $13(48)$ & 1561 (46.9) & & $9(40.9)$ & $\begin{array}{l}1565 \\
(46.9)\end{array}$ & & $176(54.2)$ & $\begin{array}{l}1398 \\
(46.1)\end{array}$ & \\
\hline $\begin{array}{l}\mathrm{BMI}\left(\mathrm{Kg} / \mathrm{m}^{2}\right) \\
\text { median(IQR) }\end{array}$ & & $28.1(5.9)$ & $27.5(6.3)$ & $28.2(5.9)$ & 0.29 & $27.3(6)$ & $28.1(5.9)$ & 0.14 & $28.1(5.70)$ & $28.2(5.96)$ & 0.67 \\
\hline $\begin{array}{l}\text { High density } \\
\text { lipoprotein } \\
\text { (HDL) } \\
\text { mean(SD) }\end{array}$ & & $1.62(0.43)$ & $1.51(0.36)$ & $1.62(0.43)$ & 0.10 & $\begin{array}{l}1.74 \\
(0.43)\end{array}$ & $1.62(0.43)$ & 0.19 & $1.57(0.41)$ & $1.63(0.44)$ & 0.002 \\
\hline $\begin{array}{l}\text { Triglycerides } \\
\text { median(IQR) }\end{array}$ & & $1.44(0.99)$ & $1.46(1.66)$ & $1.44(0.99)$ & 0.81 & $\begin{array}{l}1.95 \\
(1.67)\end{array}$ & $1.44(0.98)$ & 0.01 & $1.51(1.06)$ & $1.44(0.97)$ & 0.03 \\
\hline
\end{tabular}




\begin{tabular}{|c|c|c|c|c|c|c|c|c|c|c|c|}
\hline $\begin{array}{l}\text { Visual Acuity } \\
\text { median (IQR) }\end{array}$ & & $83.00(6.0)$ & 76.8 (12) & $82.0(6)$ & $<0.001$ & 78.4 (18) & $83.0(6)$ & $<0.001$ & $79.0(8)$ & $83.0(6)$ & $<0.001$ \\
\hline $\begin{array}{l}\text { Spherical } \\
\text { Equivalent } \\
\text { mean(SD) }\end{array}$ & & $0.60(2.41)$ & $1.53(1.93)$ & $0.60(2.41)$ & 0.02 & $\begin{array}{l}-0.05 \\
(2.47)\end{array}$ & $0.61(2.41)$ & 0.04 & $0.33(2.41)$ & $0.63(2.41)$ & 0.01 \\
\hline \multirow[t]{3}{*}{ Cataract n(\%) } & Clear Lens & $2836(84.7)$ & $17(63)$ & 2819 (84.9) & \multirow[t]{3}{*}{0.002} & $13(61.9)$ & $\begin{array}{l}2823 \\
(84.9)\end{array}$ & \multirow[t]{3}{*}{0.01} & $194(59.7)$ & $2642(87.4)$ & \multirow[t]{3}{*}{$<0.001$} \\
\hline & Psuedophakic & $174(5.2)$ & $2(7.4)$ & $171(5.1)$ & & $4(19.0)$ & $170(5.1)$ & & $65(20.0)$ & 109 (3.6) & \\
\hline & $\begin{array}{l}\text { Phakic } \\
\text { Cataract }\end{array}$ & 339 (10.1) & $8(29.6)$ & 331 (10) & & 4 (19.0) & 334 (10.0) & & $66(20.3)$ & $273(9.0)$ & \\
\hline \multirow[t]{3}{*}{ HbA1c n(\%) } & No Diabetes & $2165(77.8)$ & $14(70)$ & 2151 (81.9) & \multirow[t]{3}{*}{0.57} & $16(84.2)$ & $2149(77.8)$ & \multirow[t]{3}{*}{0.76} & $176(69.3)$ & 1989(78.7) & \multirow[t]{3}{*}{0.003} \\
\hline & $\begin{array}{l}\text { Impaired } \\
\text { glucose } \\
\text { regulation }\end{array}$ & $344(12.4)$ & $4(20)$ & $340(12.3)$ & & $2(10.5)$ & $342(12.4)$ & & $43(16.9)$ & $301(11.9)$ & \\
\hline & Diabetes & $273(9.8)$ & $2(10)$ & $271(9.8)$ & & $1(5.3)$ & $272(9.8)$ & & 35 (13.8) & $238(9.4)$ & \\
\hline \multirow[t]{3}{*}{ Smoking n(\%) } & Never & $1817(54.3)$ & 16 (57.1) & $1802(54.2)$ & \multirow[t]{3}{*}{0.48} & $11(50.0)$ & $\begin{array}{l}1806 \\
(54.3)\end{array}$ & \multirow[t]{3}{*}{0.50} & $183(56.3)$ & $1635(54.0)$ & \multirow[t]{3}{*}{0.10} \\
\hline & Ex-smoker & $1179(35.2)$ & $11(39.3)$ & 1168 (35.2) & & 7 (31.8) & $\begin{array}{l}1172 \\
(35.2)\end{array}$ & & $119(36.6)$ & $1060(35.0)$ & \\
\hline & Current & $352(10.5)$ & $1(3.6)$ & $352(10.6)$ & & $4(18.2)$ & 349 (10.5) & & $23(7.1)$ & 330 (10.9) & \\
\hline \multirow{2}{*}{$\begin{array}{l}\text { Hypertension } \\
\mathrm{n}(\%)\end{array}$} & Normal & $828(24.8)$ & $5(20)$ & $823(24.9)$ & \multirow[t]{2}{*}{0.59} & $4(18.2)$ & $824(24.9)$ & \multirow[t]{2}{*}{0.85} & $62(19.3)$ & 766 (25.4) & \multirow[t]{2}{*}{0.04} \\
\hline & Elevated & $341(10.2)$ & $4(16)$ & $337(10.2)$ & & $3(13.6)$ & $338(10.2)$ & & 37 (11.5) & 305 (10.1) & \\
\hline
\end{tabular}




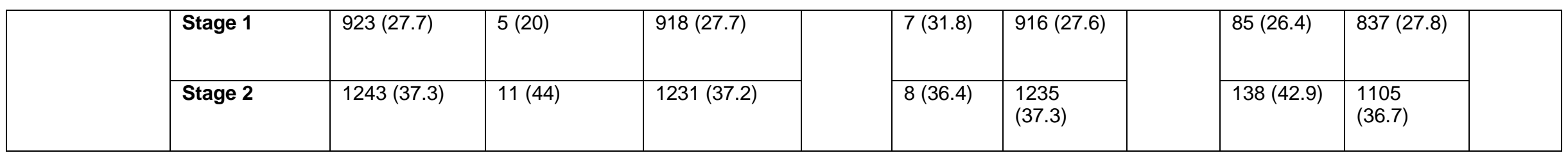

Table 2. Prevalence of vitreomacular interface features at eye level in the overall sample and age group stratified prevalence using unweighted and weighted data. Number $\mathrm{n}$, prevalence \%, and confidence intervals $\mathrm{Cl}$.

\begin{tabular}{|c|c|c|c|}
\hline $\begin{array}{l}\text { Vitreomacular } \\
\text { Interface feature }\end{array}$ & Age Groups & $\begin{array}{c}\text { Unweighted } \\
\text { Prevalence } n \text { eyes } \\
\text { n(\%,Cl) }\end{array}$ & $\begin{array}{c}\text { Weighted } \\
\text { Prevalence } n \text { eyes } \\
\text { n(\%,Cl) }\end{array}$ \\
\hline \multirow{4}{*}{$\begin{array}{c}\text { Vitreomacular } \\
\text { Traction }\end{array}$} & Total & $39(0.6,0.43-0.81)$ & $30(0.5,0.31-0.70)$ \\
\hline & $40-59$ & $1(2.6,0.13-15.1)$ & $2(0.1,0.0-0.2)$ \\
\hline & $60-69$ & $11(28.2,15.6-45.1)$ & $6(0.4,0.2-0.9)$ \\
\hline & $70+$ & $27(69.2,52.3-82.5)$ & $22(1.5,55.6-85.8)$ \\
\hline \multirow[t]{4}{*}{ Macular Hole } & Total & $31(0.5,0.33-0.67)$ & $23(0.3,0.23-0.52)$ \\
\hline & $40-59$ & $2(6.5,1.12-22.8)$ & $3(0.1,0.0-0.2)$ \\
\hline & $60-69$ & $17(54.8,36.3-72.2)$ & $9(0.6,0.3-1.2)$ \\
\hline & $70+$ & $12(38.7,22.4-57.7)$ & $11(0.8,0.4-1.4)$ \\
\hline \multirow{4}{*}{$\begin{array}{l}\text { Epiretinal } \\
\text { Membrane }\end{array}$} & Total & $602(9.1,8.42-9.82)$ & $503(7.6,7.0-8.3)$ \\
\hline & $40-59$ & $74(12.3,9.83-15.2)$ & $117(3.1,2.5-3.7)$ \\
\hline & $60-69$ & $211(35.0,31.3-39.0)$ & $116(8.3,6.9-9.9)$ \\
\hline & $70+$ & $317(52.7,48.6-56.7)$ & $270(18.9,16.9-21.1)$ \\
\hline
\end{tabular}


Table 3 Generalised estimating equation investigating associations between each vitreomacular feature and potential risk

\begin{tabular}{|c|c|c|c|c|c|c|c|c|c|c|c|c|c|}
\hline & & \multicolumn{4}{|c|}{ Vitreomacular Traction } & \multicolumn{4}{|c|}{ Macular Hole } & \multicolumn{4}{|c|}{ Epiretinal Membrane } \\
\hline & & \multicolumn{2}{|c|}{$\begin{array}{l}\text { Age and Sex } \\
\text { adjusted }\end{array}$} & \multicolumn{2}{|l|}{$\begin{array}{l}\text { Multivariate } \\
\text { adjusted }\end{array}$} & \multicolumn{2}{|c|}{$\begin{array}{l}\text { Age and Sex } \\
\text { adjusted }\end{array}$} & \multicolumn{2}{|c|}{$\begin{array}{l}\text { Multivariate } \\
\text { adjusted }\end{array}$} & \multicolumn{2}{|c|}{$\begin{array}{l}\text { Age and Sex } \\
\text { adjusted }\end{array}$} & \multicolumn{2}{|c|}{$\begin{array}{l}\text { Multivariate } \\
\text { adjusted }\end{array}$} \\
\hline & & $\begin{array}{l}\text { OR(95\%Cl } \\
\text { ) }\end{array}$ & $\begin{array}{l}\mathrm{p}- \\
\text { value }\end{array}$ & $\begin{array}{l}\text { OR(95\%Cl } \\
\text { ) }\end{array}$ & \begin{tabular}{|l|}
$\mathbf{p}-$ \\
value
\end{tabular} & $\begin{array}{l}\text { OR(95\%Cl } \\
\text { ) }\end{array}$ & $\begin{array}{l}p- \\
\text { value }\end{array}$ & $\begin{array}{l}\text { OR(95\%Cl } \\
\text { ) }\end{array}$ & \begin{tabular}{|l|}
$p-$ \\
value
\end{tabular} & $\begin{array}{l}\text { OR(95\%Cl } \\
\text { ) }\end{array}$ & $\begin{array}{l}p- \\
\text { value }\end{array}$ & $\begin{array}{l}\text { OR(95\%Cl } \\
\text { ) }\end{array}$ & $\begin{array}{l}\mathrm{p}- \\
\text { value }\end{array}$ \\
\hline \multirow[t]{3}{*}{ Age group } & 40-59 & Ref & Ref & Ref & Ref & Ref & Ref & Ref & Ref & Ref & Ref & Ref & Ref \\
\hline & $60-69$ & \begin{tabular}{|l|}
$10.67(2.38$ \\
$-47.91)$
\end{tabular} & $0.002^{+}$ & \begin{tabular}{|l}
$7.07(1.53-$ \\
$32.6)$
\end{tabular} & \begin{tabular}{|l|}
0.01 \\
\end{tabular} & \begin{tabular}{|l|}
$8.47(2.75-$ \\
$26.11)$
\end{tabular} & $\begin{array}{l}<<0.001 \\
+\end{array}$ & \begin{tabular}{|l|}
$4.62(1.54-$ \\
$13.88)$
\end{tabular} & 0.01 & $\begin{array}{l}2.85(2.16- \\
3.77)\end{array}$ & \begin{tabular}{|l}
$<0.001$ \\
+
\end{tabular} & \begin{tabular}{|l|}
$1.97(1.34-$ \\
$2.89)$
\end{tabular} & 0.001 \\
\hline & $70+$ & $\begin{array}{l}40.52(9.59 \\
-171.14)\end{array}$ & $\begin{array}{l}<0.001 \\
+\end{array}$ & \begin{tabular}{|l}
$25.2(5.92-$ \\
$107.7)$
\end{tabular} & \begin{tabular}{|l|}
$<0.00$ \\
1
\end{tabular} & \begin{tabular}{|l}
$9.44(3.04-$ \\
$29.29)$
\end{tabular} & $\begin{array}{l}<0.001 \\
+\end{array}$ & $\begin{array}{l}4.65(1.28- \\
16.85)\end{array}$ & 0.02 & $\begin{array}{l}7.20(5.53- \\
9.38)\end{array}$ & $\begin{array}{l}<0.001 \\
+\end{array}$ & \begin{tabular}{|l}
$4.61(3.08-$ \\
$6.90)$
\end{tabular} & $\begin{array}{l}<0.00 \\
1\end{array}$ \\
\hline \multirow[t]{2}{*}{ Sex } & Female & $\begin{array}{l}1.23(0.62- \\
2.42)\end{array}$ & $0.56^{*}$ & $\begin{array}{l}1.20(0.59- \\
2.44)\end{array}$ & 0.62 & $\begin{array}{l}2.02(0.97- \\
4.19)\end{array}$ & $0.06^{*}$ & $\begin{array}{l}1.49(0.65- \\
3.42)\end{array}$ & 0.35 & $\begin{array}{l}0.79(0.64- \\
0.98)\end{array}$ & $0.03^{*}$ & $\begin{array}{l}0.69(0.52- \\
0.91)\end{array}$ & 0.01 \\
\hline & Male & Ref & Ref & Ref & Ref & Ref & Ref & Ref & Ref & Ref & Ref & Ref & Ref \\
\hline BMI $\left(\mathrm{Kg} / \mathrm{m}^{2}\right)$ & & \begin{tabular}{|l|}
$0.10(0.00-$ \\
$20.7)$
\end{tabular} & 0.40 & & & \begin{tabular}{|l|}
$0.06(0.00-$ \\
$5.33)$
\end{tabular} & 0.22 & & & $\begin{array}{l}0.77(0.18- \\
3.42)\end{array}$ & 0.74 & & \\
\hline HDL & & $\begin{array}{l}0.57(0.25- \\
1.28)\end{array}$ & 0.17 & & & \begin{tabular}{|l}
$1.67(0.85-$ \\
$3.29)$
\end{tabular} & 0.14 & $\begin{array}{l}3.33(1.64- \\
6.53)\end{array}$ & $\begin{array}{l}<0.00 \\
1\end{array}$ & $\begin{array}{l}0.94(0.72- \\
1.23)\end{array}$ & 0.66 & $\begin{array}{l}1.00(0.69- \\
1.44)\end{array}$ & 0.99 \\
\hline $\begin{array}{l}\text { Triglyceride } \\
\text { s }\end{array}$ & & $\begin{array}{l}1.02(0.11- \\
9.37)\end{array}$ & 0.98 & & & \begin{tabular}{|l|}
$10.93(1.40$ \\
$-85.47)$
\end{tabular} & 0.02 & $\begin{array}{l}22.3(2.90- \\
171.2)\end{array}$ & 0.003 & $\begin{array}{l}1.90(1.09- \\
3.29)\end{array}$ & 0.02 & \begin{tabular}{|l}
$2.11(1.06-$ \\
$4.21)$
\end{tabular} & 0.03 \\
\hline
\end{tabular}




\begin{tabular}{|c|c|c|c|c|c|c|c|c|c|c|c|c|c|}
\hline $\begin{array}{l}\text { Visual } \\
\text { Acuity }\end{array}$ & & $\begin{array}{l}0.97(0.95- \\
0.99)\end{array}$ & $<0.001$ & $\begin{array}{l}0.97(0.95- \\
0.99)\end{array}$ & 0.001 & $\begin{array}{l}0.96(0.94- \\
0.97)\end{array}$ & $<0.001$ & $\begin{array}{l}0.95(0.94- \\
0.97)\end{array}$ & $\begin{array}{l}<0.00 \\
1\end{array}$ & $\begin{array}{l}0.98(0.97- \\
0.98)\end{array}$ & $<0.001$ & $\begin{array}{l}0.97(0.97- \\
0.98)\end{array}$ & $\begin{array}{l}<0.00 \\
1\end{array}$ \\
\hline $\begin{array}{l}\text { Spherical } \\
\text { Equivalent }\end{array}$ & & $\begin{array}{l}1.07(0.95- \\
1.21)\end{array}$ & 0.25 & $\begin{array}{l}1.06(0.96- \\
1.17)\end{array}$ & 0.29 & $\begin{array}{l}0.88(0.83- \\
0.94)\end{array}$ & $<0.001$ & $\begin{array}{l}0.89(0.85- \\
0.95)\end{array}$ & $\begin{array}{l}<0.00 \\
1\end{array}$ & $\begin{array}{l}0.90(0.87- \\
0.93)\end{array}$ & $<0.001$ & $\begin{array}{l}0.92(0.88- \\
0.96)\end{array}$ & 0.001 \\
\hline \multirow[t]{3}{*}{ Cataract } & Clear Lens & Ref & Ref & Ref & Ref & Ref & Ref & Ref & Ref & Ref & Ref & Ref & Ref \\
\hline & $\begin{array}{l}\text { Psuedophaki } \\
\text { c }\end{array}$ & $\begin{array}{l}0.61(1.17- \\
2.21)\end{array}$ & 0.45 & $\begin{array}{l}0.71(1.19- \\
2.70)\end{array}$ & 0.61 & $\begin{array}{l}2.75(0.93- \\
8.17)\end{array}$ & 0.07 & $\begin{array}{l}1.77(0.57- \\
5.55)\end{array}$ & 0.33 & $\begin{array}{l}3.83(2.70- \\
5.42)\end{array}$ & $<0.001$ & $\begin{array}{l}3.55(2.30- \\
5.50)\end{array}$ & $\begin{array}{l}<0.00 \\
1\end{array}$ \\
\hline & $\begin{array}{l}\text { Phakic } \\
\text { Cataract }\end{array}$ & $\begin{array}{l}1.24(0.56- \\
2.75)\end{array}$ & 0.59 & $\begin{array}{l}1.34(0.58- \\
3.13)\end{array}$ & 0.49 & $\begin{array}{l}2.07(0.72- \\
5.92)\end{array}$ & 0.18 & $\begin{array}{l}1.86(0.67- \\
5.19)\end{array}$ & 0.24 & $\begin{array}{l}1.71(1.26- \\
2.31)\end{array}$ & 0.001 & $\begin{array}{l}1.83(1.26- \\
2.64)\end{array}$ & 0.001 \\
\hline \multirow[t]{3}{*}{ HbA1c } & No Diabetes & Ref & Ref & Ref & Ref & Ref & Ref & Ref & Ref & Ref & Ref & Ref & Ref \\
\hline & $\begin{array}{l}\text { Impaired } \\
\text { glucose } \\
\text { regulation }\end{array}$ & $\begin{array}{l}1.26(0.45- \\
3.52)\end{array}$ & 0.66 & & & $\begin{array}{l}0.59(0.18- \\
1.96)\end{array}$ & 0.39 & & & $\begin{array}{l}1.15(0.84- \\
1.58)\end{array}$ & 0.39 & $\begin{array}{l}0.89(0.61- \\
1.30)\end{array}$ & 0.56 \\
\hline & Diabetes & $\begin{array}{l}0.69(0.20- \\
2.42)\end{array}$ & 0.56 & & & $\begin{array}{l}0.23(0.03- \\
1.72)\end{array}$ & 0.15 & & & $\begin{array}{l}1.15(0.80- \\
1.66)\end{array}$ & 0.45 & $\begin{array}{l}0.93(0.61- \\
1.42)\end{array}$ & 0.73 \\
\hline \multirow[t]{3}{*}{ Smoking } & Never & Ref & Ref & Ref & Ref & Ref & Ref & Ref & Ref & Ref & Ref & Ref & Ref \\
\hline & Ex-smoker & $\begin{array}{l}0.98(0.49- \\
1.96)\end{array}$ & 0.96 & & & $\begin{array}{l}1.18(0.52- \\
2.68)\end{array}$ & 0.68 & & & $\begin{array}{l}0.85(0.68- \\
1.06)\end{array}$ & 0.15 & $\begin{array}{l}0.92(0.69- \\
1.23)\end{array}$ & 0.59 \\
\hline & Current & $\begin{array}{l}0.34(0.05- \\
2.48)\end{array}$ & 0.29 & & & $\begin{array}{l}2.64(0.89- \\
7.79)\end{array}$ & 0.08 & & & $\begin{array}{l}0.77(0.51- \\
1.16)\end{array}$ & 0.21 & $\begin{array}{l}0.86(0.51- \\
1.43)\end{array}$ & 0.55 \\
\hline \multirow{2}{*}{$\begin{array}{l}\text { Hypertensio } \\
\text { n }\end{array}$} & Normal & Ref & Ref & Ref & Ref & Ref & Ref & Ref & Ref & Ref & Ref & Ref & Ref \\
\hline & Elevated & $\begin{array}{l}1.63(0.35- \\
3.88)\end{array}$ & 0.81 & & & $\begin{array}{l}1.01(0.29- \\
3.51)\end{array}$ & 0.99 & & & $\begin{array}{l}0.91(0.62- \\
1.35)\end{array}$ & 0.63 & $\begin{array}{l}1.11(0.68- \\
1.80)\end{array}$ & 0.69 \\
\hline
\end{tabular}




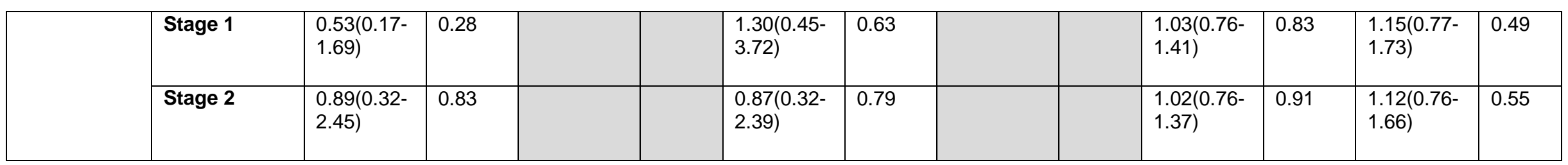

Table 4. Characteristics of sub-sample of participants included in analysis according to vitreomacular adhesion status and vitreomacular adhesion area. Generalised estimating equation investigating associations between vitreomacular adhesion and potential risk factors and vitreomacular adhesion area and potential risk factors. Each feature was adjusted for age* and gender $†$ and multivariate adjustment.

\begin{tabular}{|c|c|c|c|c|c|c|c|c|c|c|c|c|c|c|}
\hline \multirow{3}{*}{$\begin{array}{l}\text { Characteristic } \\
\text { Number }\end{array}$} & & \multicolumn{4}{|c|}{ Vitreomacular Adhesion } & \multicolumn{4}{|c|}{ Vitreomacular Adhesion } & \multicolumn{5}{|c|}{ Vitreomacular Adhesion Area $\mathrm{mm}^{2}$} \\
\hline & & $\begin{array}{l}\text { Participants } \\
\text { with gradable } \\
\text { images }\end{array}$ & $\begin{array}{l}\text { Participants } \\
\text { with VMA } \\
\text { Present }\end{array}$ & $\begin{array}{l}\text { Participants } \\
\text { with VMA } \\
\text { Absent }\end{array}$ & p value & \multicolumn{2}{|c|}{$\begin{array}{l}\text { Age and Sex } \\
\text { adjusted }\end{array}$} & \multicolumn{2}{|c|}{$\begin{array}{l}\text { Multivariate } \\
\text { adjusted }\end{array}$} & \multirow{2}{*}{$\begin{array}{l}\begin{array}{l}\text { VMA } \\
\text { Area } \\
\mathrm{mm}^{2}\end{array} \\
\mathrm{~N}=395\end{array}$} & \multicolumn{2}{|c|}{$\begin{array}{l}\text { Age and Sex } \\
\text { adjusted }\end{array}$} & \multicolumn{2}{|c|}{ Multivariate adjusted } \\
\hline & & $\mathrm{N}=1481$ & $\mathrm{~N}=514$ & $\mathrm{~N}=967$ & & $\begin{array}{l}\text { OR } \\
(95 \% \mathrm{Cl})\end{array}$ & \begin{tabular}{|l|}
$p$-value \\
\end{tabular} & $\begin{array}{l}\text { OR } \\
(95 \% \mathrm{Cl})\end{array}$ & \begin{tabular}{|l}
$p$-value \\
\end{tabular} & & \begin{tabular}{|l|} 
OR \\
$(95 \% \mathrm{Cl})$
\end{tabular} & p-value & OR(95\%Cl) & $p$-value \\
\hline \multirow[t]{3}{*}{ Age group $\mathrm{n}(\%)$} & $40-59$ & $829(55.9)$ & $303(58.9)$ & $525(54.3)$ & $<0.001$ & Ref & Ref & Ref & Ref & $\begin{array}{l}289 \\
(73.2)\end{array}$ & Ref & Ref & Ref & Ref \\
\hline & $60-69$ & $321(21.7)$ & $136(26.5)$ & $186(19.2)$ & & $\begin{array}{l}1.22(1.01 \\
-1.46)\end{array}$ & $0.04+$ & $\begin{array}{l}1.27(1.05 \\
-1.55)\end{array}$ & 0.02 & $\begin{array}{l}69 \\
(17.7)\end{array}$ & $\begin{array}{l}0.001(0.00- \\
0.01)\end{array}$ & $\begin{array}{l}<0.001 \\
+\end{array}$ & $\begin{array}{l}0.03(0.01- \\
0.09)\end{array}$ & $<0.001$ \\
\hline & $70+$ & $331(22.4)$ & $75(14.6)$ & 256 (26.5) & & $\begin{array}{l}0.52(0.41 \\
-0.68)\end{array}$ & $\begin{array}{l}<0.001 \\
+\end{array}$ & $\begin{array}{l}0.57(0.42 \\
-0.76)\end{array}$ & \begin{tabular}{l|l|}
$<0.001$ \\
\end{tabular} & $37(9.1)$ & \begin{tabular}{|l|}
$0.03(0.01-$ \\
$0.08)$
\end{tabular} & $\begin{array}{l}<0.001 \\
+\end{array}$ & $\begin{array}{l}0.001(0.00- \\
0.01)\end{array}$ & $<0.001$ \\
\hline Gender n(\%) & Female & $791(53.4)$ & $260(50.6)$ & $532(55.0)$ & 0.10 & $\begin{array}{l}0.80(0.68 \\
-0.95)\end{array}$ & $0.01^{*}$ & $\begin{array}{l}0.79(0.66 \\
-0.94)\end{array}$ & 0.01 & $\begin{array}{l}216 \\
(54.7)\end{array}$ & \begin{tabular}{|l|}
$0.85(0.37-$ \\
$1.92)$
\end{tabular} & 0.69 & $\begin{array}{l}1.24(0.48- \\
3.21)\end{array}$ & 0.66 \\
\hline
\end{tabular}




\begin{tabular}{|c|c|c|c|c|c|c|c|c|c|c|c|c|c|c|}
\hline & Male & 690 (46.6) & 254 (49.4) & $435(45.0)$ & & Ref & Ref & Ref & Ref & $\begin{array}{l}179 \\
(45.3)\end{array}$ & Ref & Ref & Ref & Ref \\
\hline $\begin{array}{l}\mathrm{BMI}\left(\mathrm{Kg} / \mathrm{m}^{2}\right) \\
\text { median(IQR) }\end{array}$ & & $28.0(5.9)$ & $27.9(5.6)$ & $27.9(5.9)$ & 0.84 & $\begin{array}{l}0.69(0.22 \\
-2.18)\end{array}$ & 0.53 & & & $\begin{array}{l}28.1 \\
(5.96)\end{array}$ & $\begin{array}{l}\text { 7.88(0.01- } \\
6091)\end{array}$ & 0.54 & & \\
\hline $\begin{array}{l}\text { High density } \\
\text { lipoprotein } \\
\text { (HDL) } \\
\text { mean(SD) }\end{array}$ & & $1.60(0.44)$ & $1.59(0.44)$ & $1.60(0.44)$ & 0.47 & $\begin{array}{l}0.97(0.78 \\
-1.20)\end{array}$ & 0.78 & & & $\begin{array}{l}1.61(0.4 \\
2)\end{array}$ & $\begin{array}{l}0.54(0.1+- \\
1.55)\end{array}$ & 0.25 & & \\
\hline $\begin{array}{l}\text { Triglycerides } \\
\text { median(IQR) }\end{array}$ & & $1.45(1.00)$ & $1.42(0.90)$ & $1.45(1.02)$ & 0.99 & $\begin{array}{l}0.87(0.59 \\
-1.27)\end{array}$ & 0.46 & & & $\begin{array}{l}1.48(0.9 \\
9)\end{array}$ & $\begin{array}{l}3.35(0.55- \\
20.2)\end{array}$ & 0.19 & & \\
\hline $\begin{array}{l}\text { Visual Acuity } \\
\text { median (IQR) }\end{array}$ & & $83.0(6)$ & $83.0(5)$ & $83.0(6)$ & 0.06 & $\begin{array}{l}1.00(0.99 \\
-1.00)\end{array}$ & 0.86 & & & $\begin{array}{l}84.0(6.0 \\
)^{-1}\end{array}$ & $\begin{array}{l}1.01(0.98- \\
1.04)\end{array}$ & 0.50 & $\begin{array}{l}1.00(0.97- \\
1.04)\end{array}$ & 0.98 \\
\hline $\begin{array}{l}\text { Spherical } \\
\text { Equivalent } \\
\text { mean(SD) }\end{array}$ & & $0.51(2.60)$ & $0.60(2.62)$ & $0.49(2.60)$ & 0.37 & $\begin{array}{l}1.03(0.99 \\
-1.08)\end{array}$ & 0.11 & & & $\begin{array}{l}0.24(2.4 \\
0)\end{array}$ & $\begin{array}{l}1.25(1.04- \\
1.50)\end{array}$ & 0.02 & $\begin{array}{l}1.23(1.02- \\
1.48)\end{array}$ & 0.03 \\
\hline \multirow[t]{3}{*}{ Cataract n(\%) } & Clear Lens & $1262(85.3)$ & 463 (90.1) & 799 (82.7) & \multirow[t]{3}{*}{$<0.001$} & Ref & Ref & Ref & Ref & $\begin{array}{l}370(93 . \\
7)\end{array}$ & Ref & Ref & Ref & Ref \\
\hline & $\begin{array}{l}\text { Psuedopha } \\
\text { kic }\end{array}$ & $88(5.9)$ & $15(2.9)$ & $73(7.6)$ & & $\begin{array}{l}0.50(0.31 \\
-0.81)\end{array}$ & 0.01 & $\begin{array}{l}0.50(0.30 \\
-0.83)\end{array}$ & 0.01 & $7(1.8)$ & $\begin{array}{l}0.14(0.01- \\
1.61)\end{array}$ & 0.11 & $\begin{array}{l}1.51(0.30- \\
7.66)\end{array}$ & 0.62 \\
\hline & $\begin{array}{l}\text { Phakic } \\
\text { Cataract }\end{array}$ & $129(8.7)$ & $36(7.0)$ & $94(9.7)$ & & $\begin{array}{l}0.83(0.60 \\
-1.16)\end{array}$ & 0.27 & $\begin{array}{l}0.84(0.60 \\
-1.19)\end{array}$ & 0.33 & $18(4.6)$ & $\begin{array}{l}0.23(0.04- \\
1.45)\end{array}$ & 0.12 & $\begin{array}{l}2.42(0.57- \\
10.3)\end{array}$ & 0.23 \\
\hline \multirow[t]{3}{*}{ HbA1c n(\%) } & $\begin{array}{l}\text { No } \\
\text { Diabetes }\end{array}$ & $1015(72.7)$ & 341 (71.3) & 674 (73.3) & \multirow[t]{3}{*}{0.24} & Ref & Ref & Ref & Ref & $\begin{array}{l}288 \\
(78.3)\end{array}$ & Ref & Ref & Ref & Ref \\
\hline & $\begin{array}{l}\text { Impaired } \\
\text { glucose } \\
\text { regulation }\end{array}$ & $218(15.6)$ & $85(17.8)$ & 133 (14.5) & & $\begin{array}{l}1.30(1.03 \\
-1.65)\end{array}$ & 0.03 & $\begin{array}{l}1.32(1.04 \\
-1.67)\end{array}$ & 0.02 & $54(14.7)$ & $\begin{array}{l}1.00(0.27- \\
3.70)\end{array}$ & 0.99 & & \\
\hline & Diabetes & 164 (11.7) & $52(10.9)$ & 112 (12.2) & & $\begin{array}{l}1.02(0.77 \\
-1.34)\end{array}$ & 0.92 & $\begin{array}{l}1.02(0.77 \\
-1.34)\end{array}$ & 0.91 & $26(7.0)$ & $\begin{array}{l}0.93(0.17- \\
5.16)\end{array}$ & 0.93 & & \\
\hline
\end{tabular}




\begin{tabular}{|c|c|c|c|c|c|c|c|c|c|c|c|c|c|c|}
\hline \multirow[t]{3}{*}{ Smoking n(\%) } & Never & 805 (54.4) & 269 (52.3) & 536 (55.5) & \multirow[t]{3}{*}{0.22} & Ref & Ref & Ref & Ref & $\begin{array}{l}212 \\
(53.8)\end{array}$ & Ref & Ref & Ref & Ref \\
\hline & Ex-smoker & 528 (35.7) & $185(36.0)$ & $343(35.5)$ & & $\begin{array}{l}1.07(0.89 \\
-1.29)\end{array}$ & 0.45 & & & $\begin{array}{l}139 \\
(35.1)\end{array}$ & $\begin{array}{l}0.81(0.35- \\
1.87)\end{array}$ & 0.61 & & \\
\hline & Current & $147(10.0)$ & 60 (11.7) & $87(9.0)$ & & $\begin{array}{l}1.02(0.78 \\
-1.29)\end{array}$ & 0.45 & & & $\begin{array}{l}44 \\
(11.1)\end{array}$ & $\begin{array}{l}1.65(0.40- \\
6.89)\end{array}$ & 0.49 & & \\
\hline \multirow[t]{4}{*}{$\begin{array}{l}\text { Hypertension } \\
\mathrm{n}(\%)\end{array}$} & Normal & $373(25.3)$ & $135(26.3)$ & $238(24.7)$ & \multirow[t]{4}{*}{0.37} & Ref & Ref & Ref & Ref & $\begin{array}{l}103 \\
(26.1)\end{array}$ & Ref & Ref & Ref & Ref \\
\hline & Elevated & 135 (9.1) & $38(7.4)$ & $97(10.1)$ & & $\begin{array}{l}0.80(0.57 \\
-1.13)\end{array}$ & 0.21 & & & $\begin{array}{l}40 \\
(10.2)\end{array}$ & $\begin{array}{l}4.56(0.82- \\
25.5)\end{array}$ & 0.09 & $\begin{array}{l}2.67(0.41- \\
17.40)\end{array}$ & 0.31 \\
\hline & Stage 1 & $393(26.6)$ & $136(26.5)$ & $257(26.7)$ & & $\begin{array}{l}0.92(0.72 \\
-1.16)\end{array}$ & 0.46 & & & $\begin{array}{l}\text { 123(31. } \\
\text { 2) }\end{array}$ & $\begin{array}{l}1.25(0.40- \\
3.87)\end{array}$ & 0.70 & $\begin{array}{l}0.77(0.21- \\
2.78)\end{array}$ & 0.69 \\
\hline & Stage 2 & $575(39.0)$ & 205 (39.9) & $370(38.5)$ & & $\begin{array}{l}0.96(0.77 \\
-1.21)\end{array}$ & 0.73 & & & $\begin{array}{l}129 \\
(32.5)\end{array}$ & $\begin{array}{l}0.32(0.11- \\
0.92)\end{array}$ & 0.03 & $\begin{array}{l}0.21(0.06- \\
0.67)\end{array}$ & 0.01 \\
\hline
\end{tabular}

Table 2 Characteristics of participants with gradable and ungradable images, NICOLA Study 2013-2018. Weights were applied to measure the number of people in the population that are represented by each member of the sample.

\begin{tabular}{|l|l|l|l|l|}
\hline & & $\begin{array}{l}\text { Participants with } \\
\text { gradable images } \\
\text { n(\%) }\end{array}$ & $\begin{array}{l}\text { Participants with } \\
\text { ungradable images n(\%) }\end{array}$ & P value \\
\hline Number & $\mathbf{3 3 5 8 ( 9 8 )}$ & $\mathbf{6 2 ( 2 )}$ & \\
\hline Age group $\mathrm{n( \% )}$ & $\mathbf{4 0 - 5 9}$ & $1926(57.3)$ & $24(38.6)$ & 0.01 \\
\hline & $\mathbf{6 0 - 6 9}$ & $703(20.9)$ & $15(24.1)$ & \\
\hline & $\mathbf{7 0 +}$ & $729(21.7)$ & $23(37.3)$ & \\
\hline
\end{tabular}




\begin{tabular}{|c|c|c|c|c|}
\hline Gender n(\%) & Female & 1784 (53.1) & \begin{tabular}{|l|}
$29(46.5)$ \\
\end{tabular} & \multirow[t]{2}{*}{0.30} \\
\hline & Male & $1574(46.9)$ & 33 (53.5) & \\
\hline $\begin{array}{l}\text { BMI }\left(\mathrm{Kg} / \mathrm{m}^{2}\right) \\
\text { median(IQR) }\end{array}$ & & $28.9(5.15)$ & $29.5(5.6)$ & 0.41 \\
\hline $\begin{array}{l}\text { High density } \\
\text { lipoprotein (HDL) } \\
\text { mean(SD) }\end{array}$ & & $1.62(0.44)$ & $1.57(0.4)$ & 0.40 \\
\hline $\begin{array}{l}\text { Triglycerides } \\
\text { median(IQR) }\end{array}$ & & $1.63(0.95)$ & $1.67(1.08)$ & 0.80 \\
\hline $\begin{array}{l}\text { Visual Acuity } \\
\text { median (IQR) }\end{array}$ & & $82.00(6.0)$ & $80.0(10.0)$ & $<0.001$ \\
\hline $\begin{array}{l}\text { Spherical } \\
\text { Equivalent } \\
\text { mean(SD) }\end{array}$ & & $0.60(2.41)$ & $0.53(4.03)$ & 0.82 \\
\hline \multirow[t]{3}{*}{ Cataract n (\%) } & Clear Lens & $2213(65.9)$ & $42(68.0)$ & \multirow[t]{3}{*}{0.20} \\
\hline & Psuedophakic & $442(13.2)$ & $4(5.9)$ & \\
\hline & $\begin{array}{l}\text { Phakic } \\
\text { Cataract }\end{array}$ & 703 (20.9) & $16(26.1)$ & \\
\hline \multirow[t]{3}{*}{ HbA1c n(\%) } & No Diabetes & $2275(81.8)$ & $32(71.0)$ & \multirow[t]{3}{*}{0.15} \\
\hline & $\begin{array}{l}\text { Impaired } \\
\text { glucose } \\
\text { regulation }\end{array}$ & $233(8.4)$ & $5(11.6)$ & \\
\hline & Diabetes & $273(9.8)$ & $8(17.4)$ & \\
\hline \multirow[t]{2}{*}{ Smoking $n(\%)$} & Never & $1817(54.3)$ & $26(42.3)$ & \multirow[t]{2}{*}{0.18} \\
\hline & Ex-smoker & 1179 (35.2) & 28 (44.9) & \\
\hline
\end{tabular}


728

729

730

731

732

733

734

735

736

737

738

739

740

741

742

743

33

34

35

737

38

39

41

\begin{tabular}{|l|l|l|l|l|}
\hline & Current & $352(10.5)$ & $8(12.8)$ & \\
\hline Hypertension n(\%) & Normal & $828(24.7)$ & $15(23.4)$ & 0.47 \\
\hline & Elevated & $341(10.2)$ & $8(12.6)$ & \\
\hline & Stage 1 & $923(27.6)$ & $12(19.6)$ & \\
\hline & Stage 2 & $1253(37.5)$ & $27(44.4)$ & \\
\hline
\end{tabular}


Table 3 Relationship of other ocular diseases and conditions to prevalence of vitreomacular interface features.

¥Too few participants to obtain reliable estimate. CA = Condition Absent. CP = Condition Present.

\begin{tabular}{|c|c|c|c|c|c|c|c|c|c|c|c|}
\hline & & & \multicolumn{3}{|c|}{ VMT } & \multicolumn{3}{|c|}{$\mathrm{MH}$} & \multicolumn{3}{|c|}{ ERM } \\
\hline Condition & CA(N) & $\mathrm{CP}(\mathrm{N})$ & CA N(\%) & CP N(\%) & $P$ value & CA N(\%) & CP N(\%) & P value & CA N(\%) & CP N(\%) & $P$ value \\
\hline GA & 6217 & 14 & $14(0.2)$ & $0(0.0)$ & $\neq$ & $13(0.2)$ & $1(5.3)$ & $<0.001$ & $(10) 0.2$ & $3(0.7)$ & 0.03 \\
\hline CNV & 6218 & 13 & $12(0.2)$ & $1(3.4)$ & $<0.001$ & $13(0.2)$ & $0(0.0)$ & $*$ & (7)0.1 & $6(1.4)$ & $<0.001$ \\
\hline DR & 6153 & 77 & $75(1.2)$ & 2(6.9) & 0.01 & $77(1.2)$ & $0(0.0)$ & $\neq$ & (69)1.2 & $9(2.0)$ & 0.13 \\
\hline Occlusion & 6219 & 12 & 11(0.2) & $1(3.4)$ & $<0.001$ & $12(0.2)$ & $0(0.0)$ & 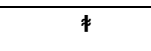 & (8)0.1 & $4(0.9)$ & $<0.001$ \\
\hline
\end{tabular}


Table 4. Relationship of other ocular diseases and conditions to presence of VMA and VMA area measurement calculated in participants.

757 抽 few participants to obtain reliable estimate. $\mathrm{CA}=$ Condition Absent. $\mathrm{CP}=$ Condition Present.

\begin{tabular}{|l|l|l|l|l|l|}
\hline \multicolumn{2}{|l|}{} & \multicolumn{3}{c|}{ VMA } \\
\hline Condition & CA(N) & CP(N) & CA N(\%) & CP N(\%) & P value \\
\hline GA & 2730 & 3 & $2(0.1)$ & $1(0.1)$ & 0.78 \\
\hline CNV & 2726 & 7 & $7(0.3)$ & $0(0.0)$ & $*$ \\
\hline DR & 2691 & 40 & $30(1.5)$ & $10(1.4)$ & 0.86 \\
\hline Occlusion & 2726 & 6 & $4(0.2)$ & $2(0.3)$ & 0.69 \\
\hline
\end{tabular}

